DOI: 10.20472/EFC.2019.011.011

\title{
MIROSLAV MATEEV
}

American University in the Emirates, United Arab Emirates

\section{REGULATION AND OWNERSHIP EFFECT ON BANKS PERFORMANCE: NEW EVIDENCE FROM THE MENA REGION}

\begin{abstract}
:
This paper investigates the impact of regulation and ownership on the performance of banks in 19 countries in the Middle East and North Africa (MENA) region, over a period of 11 years (2005 - 2015). We test the hypothesis that the effect of regulation on efficiency and profitability depends on the type of bank ownership. We find that only capital regulations have a strong impact on bank efficiency, but this effect does not depend on the level of ownership concentration of the bank. In line with previous empirical studies, we find that the impact of regulatory measures on bank profitability does not depend on bank ownership type. We also investigate whether the impact of regulation and ownership is different between conventional and Islamic banks, and find that the interaction effect of bank regulations and different types of ownership on a bank's profitability is strongly significant only in the sample of Islamic banks. The analysis of bank performance before and after the recent global financial crisis reveals that bank regulations have no influence on cost efficiency of a conventional bank either before or after the crisis; however, the impact on an Islamic bank's efficiency is strongly significant in the full sample period and the post-crisis period.
\end{abstract}

\section{Keywords:}

global financial crisis, ownership, bank regulation, efficiency, profitability

JEL Classification: G21, G28 


\section{Introduction}

This study investigates the impact of bank regulation and ownership on the performance of banks in the countries that belong to the Middle East and North Africa (MENA) region. The financial markets are unique in the MENA region as compared to the rest of the world given the stronger reliance on bank finance, and the higher level of governance ownership in banks, especially in the oil exporting countries (Haque \& Brown, 2017). Therefore, investigating the issue of the impact of regulation and ownership on bank performance in this region is an important contribution to the existing literature. More specifically, we address the following two questions: How do bank regulation and ownership impact on the efficiency and profitability of banks in the MENA region? Was the performance of Islamic banks (IBs) before, during and after the global financial crisis of 2007-2008 different as compared to conventional banks (CBs)?

Despite the importance of financial reforms in the MENA region, there are still a limited number of studies that examine the impact of regulation and ownership on bank performance in the MENA region. This is surprising for at least two reasons. First, the issue of performance of banks is profoundly imperative for policy makers in the MENA region attempting to mitigate the severity of any financial crisis on the overall performance of their countries. Therefore, mitigating the negative impact of such financial crisis on bank performance is a key objective of policy makers in the MENA region. Second, the well-documented relation between financial development and growth (Levine, 1997; Levine and Zervos, 1998; Khan and Senhadji, 2000), especially in developing countries, points out that countries with lower sensitivity to negative impacts of shocks, tend to grow faster and are more stable over the long run. As the MENA region is facing numerous changes, such as opening up of their markets to foreign competition, expansion of the private sector, and increasing the role of bank lending, there is a need to strengthen banking supervision and regulation by conforming to international Basel standards and especially to the capital requirements (Bitar et al., 2016).

This paper investigates the impact of regulation and ownership on bank efficiency and profitability using a sample of 309 banks in 19 countries from the MENA region, over a period of 11 years (2005-2015). We also address the question of whether the impact of regulation and ownership is different between conventional and Islamic banking. We contribute to the empirical literature in several ways. First, prior literature finds capital regulations to have a positive effect on bank efficiency (Chortareas et al., 2012; Barth et al., 2013), with activity restrictions having a negative impact on efficiency; however, opposite effects of capital regulation and activity restrictions are reported by Pasiouras et al., (2009) and Sassi (2013). In a similar study, Haque and Brown (2017) find that government ownership, capital stringency and market power have a positive effect on cost efficiency, whereas the effect of activity restrictions and deposit insurance is 
negative. Using a larger sample of banks and a different time span, we find evidence that only capital regulation has a positive influence on bank efficiency, whereas ownership structure seems to play no role in explaining a bank's cost efficiency. However, the relationship between bank regulations and profitability is strongly significant even when we control for specific bank-level characteristics and country effects.

Second, previous research reports that the effect of regulation may depend on the type of bank ownership (more specifically, ownership concentration, government ownership and foreign ownership) in the MENA region (Haque and Brown, 2017). We find capital regulation to have a significant impact on a bank's efficiency, but this effect does not depend on the level of ownership concentration of the bank. However, the influence of bank regulations on a bank's efficiency is strongly significant for banks with higher level of government ownership. In line with previous empirical studies, we find that the impact of regulatory measures on a bank's profitability does not depend on the ownership structure.

Third, the question of whether the impact of regulation and ownership is different between conventional and Islamic banking has not been investigated so far. We find that individually regulatory measures have no impact on CB efficiency, but this effect is significant for the banks with higher level of government ownership. The influence of regulations on cost efficiency is much more pronounced in the sample of Islamic banks. Our analysis finds a significant difference in the effect of regulation and ownership on the profitability of a CB and an IB. The impact on the profitability of a CBs does not depend on the ownership structure of the bank. In contrast, the interaction effect of bank regulations and different types of bank ownership is strongly significant in the sample of Islamic banks.

Finally, our paper extends the empirical literature on regulation and ownership by focusing on the response of banks in the MENA region for an extended period before and after the crisis. A recent study of Islamic banks in the GCC region by Belanès et al. (2015) reports a slight decline in Islamic bank efficiency further to the subprime crisis just like their conventional peers all over the world. We find that bank regulations have no influence on cost efficiency of a CB either before or after the crisis; however, the impact of regulations on an Islamic bank's efficiency is strongly significant in the full sample period and the post-crisis period. Regarding the bank ownership structure, the evidence shows that foreign ownership did have a negative (positive) impact on the profitability of CBs (IBs), both before and after the crisis.

The paper proceeds as follows. In section 2 we present the main findings of our analysis of the existing literature and formulate our hypotheses. In Section 3, we introduce the data set and the methodology that we use. In Section 4, we examine the effect of regulation and ownership on bank performance while controlling for bank-level 
characteristics and country macroeconomic conditions. Section 5 presents robustness checks and alternative specifications. We conclude in Section 6.

\section{Literature review and empirical hypotheses}

\subsection{Conventional and Islamic banking in the MENA region}

The MENA region represents a complex political and economic system. The region is not economically uniform and the political structures are not easily comparable among the MENA countries (Zeaiter and El-Khalil, 2016). Countries in this region rely on either oil product markets or leisure activity markets. The MENA region is predominantly bank based, with limited development of equities and corporate bonds with some exception for the GCC countries. For firms in the MENA region, the level of long-term debt as a percentage of total debt is extremely low, reportedly to be around $3.41 \%$ (Awartani et al., 2016). This feature of the financial systems in the countries from the MENA region could be related to the nature of corporate borrowers in the region who often have higher level of opaqueness, and where controlling shareholders influence the disclosure of information. This, in turn, causes further asymmetric information concerns for suppliers of finance (Koldertsova, 2011). However, a process of improvement has started with the introduction of corporate governance standards in the region in 2002, and became a part of the resolution process that followed the stock crashes of the largest regional stock exchanges in Saudi Arabia, United Arab Emirates and Qatar in 2006 (Haque \& Brown, 2017).

Therefore, the analysis of the performance of banks in the MENA region became an important empirical question. There are well documented evidences on the efficiency of bank institutions in the MENA region. A small subset of these evidences focuses on Islamic banking either in isolation or in comparison to conventional banking. Several authors (Rao, 2002; Al-Tamimi and Al-Amiri, 2003; Cihak and Hesse, 2008; Beck et al., 2010; Espinosa and Prasad, 2010; Beck et al., 2013), among others, have contributed to the research on the GCC region and more specifically, on Islamic banking. Shafique et al. (2012) explore various reports and studies on the recent financial crisis of 2007-2008, and conclude that Islamic banks seem to be less affected by the global financial crises. Their performance was better and the relative risk was less during the crisis, which has increased the demand for the Islamic financial system in the Western world.

In contrast to the above-mentioned studies, analyses examining the risk behavior of IBs are quite limited. Employing data for 1993-2004 on OECD economies, Cihak and Hesse (2008) document that large CBs are more stable over time than large IBs, but that small IBs are more financially stable than large IBs or small CBs. Subsequent cross-country research (Beck et al., 2013; Abedifar et al., 2013,) appears to suggest insignificant 
difference in terms of stability. However, in contrast to previous work, they find that IBs have become less financially stable over time and faced greater insolvency risk than CBs during the years of 2008-2009. Focusing primarily on the MENA region, Hasan and Dridi (2010) find pre-crisis profitability of IBs to be higher than their conventional counterparts, although these differences dwindled during the crisis, suggesting that higher pre-crisis profitability of IBs was not driven by excessive risk taking. The study argues that weak risk management practices in some IBs may have contributed to the large decline in their profitability in $2009 .^{1}$

In a more recent study, Alqahtani et al. (2016) find that IBs led (lagged) CBs in terms of profitability in the early (later) stage of the financial crisis period for a sample of IBs and CBs from the GCC region. However, no evidence was found to support the view that Islamic banking has better weathered the financial crisis. Olson and Zoubi (2011) explore the determinants of profitability of IBs and CBs in 10 MENA countries for the years 2000-2008, and find that IBs initially weathered the onslaught of the global financial crisis better than commercial banks in 2007-2008. Then, as the crisis spread to the real economy in 2009, profitability declined substantially for IBs relative to CBs. Thus, the evidences on IBs superiority over the CBs especially during the crisis period, are mixed. To shed some light on this perplexing issue, we investigate the performance of 309 banks (228 CBs and 81 IBs) from 19 countries in the MENA region, over a period of 11 years (2005 to 2015). In line with previous findings, our first hypothesis postulates:

H1: Islamic banks are more profitable and less risky than conventional banks. This effect is more pronounced in the pre-crisis period but weakens during the crisis.

\subsection{The influence of ownership on bank efficiency and profitability}

Another strand of the literature links bank ownership and risk taking. This relationship is best exemplified by considering the objective function of shareholders and the potential principal agent problems between shareholders and management. While privatelyowned banks tend to focus on profit maximization, government-owned banks might have additional considerations and not just profit maximization alone. Previous research on this aspect finds that banks controlled by managers exhibited lower risk than those in which shareholders had a controlling majority. For example, Laeven and Levine (2009) empirically estimate various aspects of bank management such as bank risk taking, the structure of ownership, and national bank regulations. They find that banks with more powerful owners tend to take greater risks since owners with greater power and

\footnotetext{
1 Amba and Almukharreq (2013) investigated the impact of the financial crisis on profitability of IBs versus commercial banks using data for 92 banks in the GCC region, over the period of 4 years (2006-2009). The study reports that the financial crisis had a negative impact on profitability of banks in the GCC countries.
} 
significant holding of cash flows have enough influence on bank managers to convince them to increase risk taking. The study also argues that equity holders have greater motivation to raise risk than outside investors and debtholders. The reason is that through the increase of risk managers generate higher return. Therefore, they will have the stimulus to enlarge the risk exposure to maximize their profit. Shehzad at al. (2010) find that ownership concentration significantly reduces bank risk at low levels of shareholder protection and supervisory control.

Similarly, Haw et al. (2010) argue that agency problems can be severe in the banking sector partly because of concentrated shareholding, which leads to connected lending and relationship banking that may result in lower bank efficiency. Nevertheless, agency theory suggests that ownership concentration enhances cash flow ownership of controlling shareholders and reduces agency costs (La Porta et al., 2002), which in turn improves bank efficiency. ${ }^{2}$ Since the quality of investor protection and bank regulation is relatively weak in the MENA region, and ownership is concentrated as a response to poor legal protection of investors, we expect a positive effect of ownership concentration on cost efficiency. A related literature (see e.g., Haw et al., 2010) suggests that government control is subject to greater agency conflicts in countries with weak legal and regulatory institutions. Likewise, government ownership brings inefficiency because of conflicts between social objectives and political interests, bureaucracy and corruption, and interest group politics (Shleifer and Vishny, 1997). Based on these observations, together with the dominance of government-controlled banks in the region, we expect government ownership to reduce bank efficiency in the MENA region.

Foreign banks face 'liabilities of foreignness' ${ }^{3}$, which includes additional operating costs in overseas markets, and the difficulties in adopting host country norms and practices (Kobeissi and Sun, 2010). These additional costs related to liabilities of foreignness can lead to lower bank efficiency. However, the global advantage hypothesis suggests that foreign banks might benefit from more advanced technologies, highly skilled labor force and better risk management practices (Lensink et al., 2008). This can help foreign banks exploit bank-specific advantages and overcome the liabilities of foreignness in less competitive host countries, leading to an improved bank efficiency. The previous evidence shows that foreign banks often outperform domestic banks in terms of profitability, cost efficiency and competitiveness in developing and emerging economies

\footnotetext{
2 In support of this argument, lannotta et al. (2007) find that ownership concentration is associated with better loan quality and lower asset risk. Shehzad et al. (2010) also find that ownership concentration significantly reduces bank risk at low levels of shareholder protection rights and supervisory control.

${ }^{3}$ In the literature on MNEs, the liability of foreignness, or the costs of doing business abroad (which result in a competitive disadvantage for an MNE sub-unit), have been broadly defined as all of the additional costs that a firm operating in a market overseas incurs compared to a local firm.
} 
(Micco et al., 2007). Considering the institutional similarity between emerging economies and MENA countries, and in line with the global advantage hypothesis (Haque \& Brown, 2017), we expect foreign ownership to exert a positive influence on the cost efficiency of a bank. The effect on bank profitability should be opposite. Based on these expectations, we test the following hypotheses:

H2a: Government ownership should have a negative influence on bank efficiency; however, the effect of ownership concentration and foreign ownership on cost efficiency should be positive.

H2b: Government ownership should exert a positive influence on bank profitability; however, the effect of ownership concentration and foreign ownership on profitability should be negative.

\subsection{The influence of regulations on bank efficiency and profitability}

The adoption of the Basel Committee requirements provides a structural framework for regulatory reform initiatives in areas such as capital adequacy, disclosures, risk management, prudential regulation and corporate governance. These reforms are intended to reduce bank risk-taking behavior and to improve efficiency.

The adoption of the Basel guidelines in the MENA region was intended to align bank regulation with the level of sophistication of a country's financial system (Rocha et al., 2011). The IMF (2008) report states that nearly $68 \%$ of the Middle Eastern, and $55 \%$ of the African countries had complied with the Basel core principles. More recently, Mohseni-Cheraghlou (2012) reports a 92 percent regional compliance with Basel II provisions in relation to the disclosure of off-balance sheet items and risk management framework. The GCC countries have also made substantial progress in relation to higher provisional rates, tightening of personal loans, and the disclosure and sharing of credit information by financial institutions (Ayadi and De Groen, 2013). A recent study of Bitar et al. (2016) examines the impact of various regulatory capital ratios on bank performance using a sample of 168 banks from 17 MENA countries. The findings suggest that the compliance with the Basel capital requirements enhances bank protection against risk and improves bank efficiency and profitability. The study also reports that the impact of capital requirements on bank performance is more noticeable for too-big-to-fail banks, banks in periods of emergency, and banks in countries with good governance.

Since the MENA region shows considerable progress in the implementation of the Basel II capital requirements and related capital regulation, this most likely will bring a more disciplined approach in bank lending decisions, leading to improved bank efficiency. Using a sample of 132 commercial banks over a period of 11 years (2002-2012), Haque 
and Brown (2017) find that bank regulations had positive effects on cost efficiency in the post-global crisis period and the full sample period, suggesting improvements in the regulatory environment in the post-crisis period following the implementation of the Basel II framework. More specifically, the study reports that capital regulation had a positive effect on cost efficiency but not in the pre-global crisis period. In a similar manner, official supervisory power had a positive influence on cost efficiency, whereas the restriction on bank activities had shown the expected negative influence on cost efficiency, but not in the pre-global crisis period. Barth et al. (2013) and Chortareas et al. (2012) also find tighter restrictions on bank activities to have an adverse effect on bank efficiency, whereas Pasiouras et al. (2009) report an opposite effect. However, the effect on bank profitability is unknown. Thus, the empirical evidence on this issue appears to be mixed. We contribute to the previous analyses by testing the following hypotheses:

H3a: Capital regulation and official supervisory power should have a positive influence on bank efficiency; however, the effect of activity restrictions on efficiency should be negative.

H3b: Capital regulation and official supervisory power should exert a negative influence on bank profitability; however, the effect of activity restrictions on profitability should be positive.

\subsection{Interaction effects of bank regulation and ownership on bank performance}

The regulatory environment characterizes how a bank is capable of acting within an economy (Barth et al., 2001). While some studies (see e.g., Laeven and Levine, 2009) posit that the effect of bank regulation depends critically on a bank's ownership structure, others (Haw et al., 2010; Shehzad et al., 2010) argue that bank regulation might constrain the effectiveness of governance mechanisms such as ownership concentration. Therefore, understanding how specific regulatory and supervisory practices affect bank performance is important. Haque and Brown (2017) find inconclusive evidence regarding the effect of ownership and bank regulation on profit efficiency of banks in the MENA region. Their results suggested that cost efficiency is better explained with ownership and regulatory variables than profit efficiency, whereas Olson and Zoubi (2011) suggest that researchers perhaps should focus more on profit efficiency than cost efficiency. Despite of the importance of this concept, there are remarkably few empirical studies, which estimate how regulation and ownership structure can explain the performance of banks in the MENA region.

The effect of regulation on bank performance can be positive or negative depending on a bank's ownership structure (Laeven and Levine, 2009). Previous studies find that the quality of investor protection and bank regulation is relatively weak in the MENA region 
(Rocha et al. 2011), and ownership is concentrated as a response to poor legal protection of investors (Omran et al., 2008). Therefore, understanding how specific regulatory and supervisory practices affect bank performance is important. Furthermore, previous research shows that the level of ownership concentration is higher in CBs, whereas IBs are characterized by a larger share of government ownership. Thus, we expect the effect of regulation to be different between CBs and IBs depending on which type of ownership prevails in each banking system. To produce more evidence on this issue, we test the following hypotheses:

H4a: The effect of bank regulation and ownership on bank efficiency should be different between conventional banks and Islamic banks.

H4b: The effect of bank regulation and ownership on bank profitability should not depend on whether a bank is a conventional bank or an Islamic bank.

\section{Data set and methodology}

\subsection{Sample selection}

Due to the unavailability of data, we use an unbalanced panel data set covering 3,383 observations from 309 banks (228 CBs and 81 IBs) based in 19 MENA countries, including the six GCC countries (Bahrain, Kuwait, Oman, Qatar, Saudi Arabia and United Arab Emirates). This study uses country-specific and bank-level data over a period of 11 years (2005-2015). The ownership and financial data are collected from the Orbis Bank Focus database, ${ }^{4}$ together with the annual reports and websites of the banks included in the sample. The period of analysis represents the years for which financial data are currently available for the 19 countries in the MENA region that have CBs or IBs in their national banking sector. In addition, we use the World Bank database on bank regulation and supervision surveys (Barth et al., 2001, 2004, 2008) and the World Bank's bank regulation and supervision survey (Survey IV) to construct indices relating to supervisory power, capital adequacy, restrictions on bank activities, and private monitoring. ${ }^{5}$ Agoraki et al. (2011) argue that these indices can be more

\footnotetext{
${ }^{4}$ Many prior studies (see e.g., Abedifar et al., 2013; Daher et al., 2015) used the Bankscope data (now Orbis) as a reliable source for IBs data.

${ }^{5}$ The Bank Regulation and Supervision Survey, carried out by the World Bank, is a unique source of comparable world-wide data on how banks are regulated and supervised around the world. The current (2012) survey provides information on bank regulation and supervision for 143 jurisdictions. It covers data since 2008, and therefore permits the examination of the recent state of bank regulation and supervision in a wide range of countries as well as comparison with the pre-crisis situation. The current fourth round of the survey started in 2011 and was completed in 2012.
} 
informative than dummy variables to construct a more harmonized measure. ${ }^{6}$ Since the World Bank data sets cover several points in time, the updated 2004-dataset is used for bank observations over 2004-2007, the revised 2008-dataset for bank observations over 2008-2010, and the current 2011-dataset for bank observations over 2011-2015. Moreover, the World Bank's World Development Indicators (WDI), IMF's International Financial Statistics, and annual reports of the central banks, are used to collect macroeconomic data.

Our sample includes both public and private banks from 19 countries in the MENA region. Table 1 reports the total number of banks in each country, number of CBs and IBs, and the number of listed banks. The last two columns represent respectively, the average number of years of observations, and the total number of observations. The data contain 3,383 bank-years of observations for the various financial variables used in the study. All data are expressed in US dollars and the definitions of the variables are provided in Appendix A. We can see that $73.79 \%$ of all banks in the sample are CBs, while the number of banks listed on different national and regional stock exchanges is $47.90 \%$. The average number of years of observations is 10.64 . Table 2 presents summary statistics of bank-level characteristics, regulatory, ownership and macroeconomic variables for the total sample of banks, during the observation period (2005-2015). We also present the sample statistics separately for CBs and IBs. We winsorize the bank-level explanatory variables at the $1 \%$ and $99 \%$ levels.

Table 1. Composition of banks by country

\begin{tabular}{|l|c|c|c|c|c|c|}
\hline Country & $\begin{array}{c}\text { Total } \\
\text { Banks }\end{array}$ & $\begin{array}{c}\text { Conventional } \\
\text { Banks }\end{array}$ & $\begin{array}{c}\text { Islamic } \\
\text { Banks }\end{array}$ & $\begin{array}{c}\text { Listed } \\
\text { Banks }\end{array}$ & $\begin{array}{c}\text { Average No. } \\
\text { of Years of } \\
\text { Obs. }\end{array}$ & $\begin{array}{c}\text { Total } \\
\text { Observations }\end{array}$ \\
\hline Algeria & 12 & 12 & 0 & 0 & 10.54 & 132 \\
\hline Bahrain & 22 & 9 & 13 & 12 & 10.56 & 242 \\
\hline Egypt & 31 & 29 & 2 & 11 & 10.81 & 341 \\
\hline $\begin{array}{l}\text { Iran (Islamic } \\
\text { Republic of) }\end{array}$ & 20 & 1 & 19 & 7 & 10.57 & 220 \\
\hline Iraq & 16 & 12 & 4 & 10 & 10.88 & 176 \\
\hline Israel & 12 & 12 & 0 & 7 & 11 & 121 \\
\hline Jordan & 15 & 13 & 2 & 13 & 10.78 & 165 \\
\hline Kuwait & 12 & 5 & 7 & 11 & 10.83 & 130 \\
\hline Lebanon & 33 & 32 & 1 & 6 & 10.80 & 361 \\
\hline Libya & 10 & 10 & 0 & 0 & 10.17 & 110 \\
\hline Morocco & 17 & 17 & 0 & 7 & 10.33 & 187 \\
\hline Oman & 9 & 7 & 2 & 7 & 10.77 & 99 \\
\hline Palestinian & 4 & 2 & 2 & 1 & 10.80 & 44 \\
\hline
\end{tabular}

6 Since the World Bank data sets cover several points in time, the updated 2004-dataset is used for bank observations over 2004-2007, the revised 2008-dataset for bank observations over 2008-2010, and the current 2011-dataset for bank observations over 2011-2015. 


\begin{tabular}{|l|c|c|c|c|c|c|}
\hline Territory & & & & & & \\
\hline Qatar & 12 & 7 & 5 & 9 & 10.62 & 132 \\
\hline Saudi Arabia & 17 & 10 & 7 & 10 & 10.79 & 187 \\
\hline $\begin{array}{l}\text { Syrian Arab } \\
\text { Republic }\end{array}$ & 12 & 9 & 3 & 9 & 9.92 & 131 \\
\hline Tunisia & 15 & 13 & 2 & 9 & 10.83 & 165 \\
\hline $\begin{array}{l}\text { United Arab } \\
\text { Emirates }\end{array}$ & 33 & 23 & 10 & 19 & 10.73 & 363 \\
\hline Yemen Total & $\mathbf{3 0 9}$ & $\mathbf{2 2 8}$ & $\mathbf{8 1}$ & $\mathbf{1 4 8}$ & $\mathbf{1 0 . 6 4}$ & $\mathbf{3 , 3 8 3}$ \\
\hline \multicolumn{2}{r|}{} \\
\hline
\end{tabular}

Source: Authors' calculations

\subsection{Measurement of bank efficiency and profitability}

Delving into the determinants of banks profitability, Demirgüc-Kunt and Huizinga (1999) find that profitability differences among banks in 80 countries over the period of 1988 1995 , could be reasonably explained by a set of bank-specific financial ratios (e.g., staff expenses to total assets, cash and securities to total assets, bank capital to total assets, size, etc.), macroeconomic variables (e.g., money supply growth, inflation, and interest rates), and industry variables (e.g., concentration and ownership structure). Several studies have followed this seminal work to examine the profitability of IBs (see e.g., Mollah et al., 2017).

Empirical studies using accounting ratios to investigate the determinants of bank performance generally adopt panel techniques rather than simple ordinary least squares. For example, Olson and Zoubi (2011) explore the determinants of profitability of IBs and CBs in 10 MENA countries over the period of 2000 to 2008, and show that larger bank size, greater dependence upon loans for revenue, higher market concentration, greater GDP growth, and higher proportions of equity capital to assets, are generally associated with greater profitability. Higher liquidity, greater provisions for loan losses, cost inefficiencies, and more reliance on debt have been indicative of lower bank profits. The study also finds that profitability is positively related to capitalization strength (measured by the equity to assets ratio), and with each bank's loan specialization ratio (measured by the degree to which a bank relies on loans relative to other earning assets). Performance is found to be negatively affected by cost inefficiencies and credit risk (measured by the loan loss provisions to total loans ratio).

In this study, we follow Bitar et al. (2016) and measure bank efficiency using cost-toincome ratio $(\mathrm{CIR})$. This ratio is used to control for any cross-bank differences in terms of efficiency; usually, a higher value indicates a lower level of efficiency. We employ earnings to total assets ratio (EARTA) as a measure of bank profitability (DemirgüçKunt et al., 2013; Anginer and Demirgüç-Kunt, 2014). For robustness check purposes, we include net interest margin (NIM) as cost efficiency measure and earnings to gross loans (EARGL) as profitability measure. The former is computed as the bank interest 
income minus bank interest expenses as a percentage of earning assets (Chortareas et al., 2012). The latter is computed as bank interest income minus bank interest expenses as a percentage of gross loans. All dependent variables are described in Appendix A.

Table 2. Descriptive statistics of banks

\begin{tabular}{|c|c|c|c|c|c|c|c|c|c|c|c|c|c|}
\hline & \multicolumn{4}{|c|}{ All banks } & \multicolumn{4}{|c|}{ Conventional Banks } & \multicolumn{4}{|c|}{ Islamic Banks } & \multirow{2}{*}{$\begin{array}{c}\begin{array}{c}\text { Differe } \\
\text { ce }\end{array} \\
p \text {-value }\end{array}$} \\
\hline & obs & Mean & $\begin{array}{c}\text { Media } \\
n\end{array}$ & $S D$ & obs & Mean & $\begin{array}{c}\text { Media } \\
n\end{array}$ & $S D$ & obs & Mean & $\begin{array}{c}\text { Media } \\
n\end{array}$ & $S D$ & \\
\hline \multicolumn{14}{|c|}{ Efficiency measures } \\
\hline $\begin{array}{l}\text { Cost-to- } \\
\text { income ratio } \\
\text { (CIR) }\end{array}$ & $\begin{array}{l}255 \\
0\end{array}$ & $\begin{array}{l}47.73 \\
\%\end{array}$ & $\begin{array}{l}45.41 \\
\%\end{array}$ & $23.62 \%$ & $\begin{array}{l}193 \\
7\end{array}$ & $\begin{array}{l}47.29 \\
\%\end{array}$ & $\begin{array}{l}45.09 \\
\%\end{array}$ & $23.44 \%$ & 613 & $\begin{array}{l}49.65 \\
\%\end{array}$ & $\begin{array}{l}46.32 \\
\%\end{array}$ & $\begin{array}{l}24.00 \\
\%\end{array}$ & 0.514 \\
\hline $\begin{array}{l}\text { Net interest } \\
\text { margin } \\
\text { (NIM) }\end{array}$ & $\begin{array}{l}257 \\
5\end{array}$ & $3.13 \%$ & $2.99 \%$ & $2.91 \%$ & $\begin{array}{l}195 \\
6\end{array}$ & $3.14 \%$ & $2.99 \%$ & $2.62 \%$ & 619 & $\begin{array}{l}3.08 \\
\%\end{array}$ & $2.97 \%$ & $\begin{array}{l}3.70 \\
\%\end{array}$ & 0.932 \\
\hline \multicolumn{14}{|c|}{ Profitability measures } \\
\hline $\begin{array}{l}\text { Earnings to } \\
\text { total assets } \\
\text { (EARTA) }\end{array}$ & $\begin{array}{l}257 \\
3\end{array}$ & $0.03 \%$ & $0.32 \%$ & $2.65 \%$ & $\begin{array}{l}195 \\
4\end{array}$ & $0.08 \%$ & $0.29 \%$ & $2.13 \%$ & 619 & $\begin{array}{l}- \\
0.40 \\
\%\end{array}$ & $0.37 \%$ & $\begin{array}{l}3.85 \\
\%\end{array}$ & 0.594 \\
\hline $\begin{array}{l}\text { Earnings to } \\
\text { gross loans } \\
\text { (EARGL) }\end{array}$ & $\begin{array}{l}254 \\
8\end{array}$ & $\overline{-}-21 \%$ & $0.68 \%$ & $12.39 \%$ & $\begin{array}{l}193 \\
8\end{array}$ & $-\overline{1.29 \%}$ & $0.64 \%$ & $10.56 \%$ & 610 & $\begin{array}{l}- \\
1.00 \\
\%\end{array}$ & $0.87 \%$ & $\begin{array}{l}17.03 \\
\%\end{array}$ & $0.013^{* *}$ \\
\hline \multicolumn{14}{|c|}{ Bank Characteristics } \\
\hline $\begin{array}{l}\text { Deposit/Ass } \\
\text { ets }\end{array}$ & $\begin{array}{l}257 \\
6 \\
\end{array}$ & $\begin{array}{l}76.88 \\
\%\end{array}$ & $\begin{array}{l}81.41 \\
\% \\
\end{array}$ & $15.61 \%$ & $\begin{array}{l}197 \\
0\end{array}$ & $\begin{array}{l}79.17 \\
\% \\
\end{array}$ & $\begin{array}{l}81.84 \\
\% \\
\end{array}$ & $11.95 \%$ & 606 & $\begin{array}{l}69.54 \\
\% \\
\end{array}$ & $\begin{array}{l}78.80 \\
\% \\
\end{array}$ & $\begin{array}{l}22.47 \\
\%\end{array}$ & $0.000^{* *}$ \\
\hline Loan/Assets & $\begin{array}{l}257 \\
6\end{array}$ & $\begin{array}{l}46.98 \\
\%\end{array}$ & $\begin{array}{l}49.94 \\
\%\end{array}$ & $20.97 \%$ & $\begin{array}{l}195 \\
5\end{array}$ & $\begin{array}{l}45.88 \\
\%\end{array}$ & $\begin{array}{l}47.68 \\
\%\end{array}$ & $20.44 \%$ & 621 & $\begin{array}{l}50.11 \\
\%\end{array}$ & $\begin{array}{l}57.00 \\
\%\end{array}$ & $\begin{array}{l}22.28 \\
\%\end{array}$ & $0.009^{* *}$ \\
\hline $\begin{array}{l}\text { Net income/ } \\
\text { Total assets }\end{array}$ & $\begin{array}{l}257 \\
8\end{array}$ & $1.33 \%$ & $1.19 \%$ & $2.55 \%$ & $\begin{array}{l}194 \\
8\end{array}$ & $1.39 \%$ & $1.22 \%$ & $1.61 \%$ & 630 & $\begin{array}{l}1.14 \\
\% \\
\end{array}$ & $1.10 \%$ & $\begin{array}{l}4.32 \\
\%\end{array}$ & 0.144 \\
\hline Tier 1 Ratio & $\begin{array}{l}124 \\
0 \\
\end{array}$ & $\begin{array}{l}17.39 \\
\% \\
\end{array}$ & $\begin{array}{l}14.96 \\
\% \\
\end{array}$ & $9.57 \%$ & 977 & $\begin{array}{l}15.67 \\
\% \\
\end{array}$ & $\begin{array}{l}14.27 \\
\% \\
\end{array}$ & $6.86 \%$ & 263 & $\begin{array}{l}23.68 \\
\%\end{array}$ & $\begin{array}{l}18.54 \\
\% \\
\end{array}$ & $\begin{array}{l}14.40 \\
\% \\
\end{array}$ & $0.001^{* *}$ \\
\hline $\begin{array}{l}\text { Tangible } \\
\text { equity }\end{array}$ & $\begin{array}{l}260 \\
6\end{array}$ & $\begin{array}{l}54.29 \\
\%\end{array}$ & $\begin{array}{l}13.00 \\
\%\end{array}$ & $\begin{array}{l}433.60 \\
\%\end{array}$ & $\begin{array}{l}197 \\
1\end{array}$ & $\begin{array}{l}19.65 \\
\%\end{array}$ & $\begin{array}{l}12.45 \\
\%\end{array}$ & $1.11 \%$ & 635 & $\begin{array}{l}1.58 \\
\%\end{array}$ & $\begin{array}{l}16.37 \\
\%\end{array}$ & $\begin{array}{l}7.84 \\
\%\end{array}$ & $0.000^{* *}$ \\
\hline Liquid asset & $\begin{array}{l}260 \\
6\end{array}$ & $\begin{array}{l}28.39 \\
\%\end{array}$ & $\begin{array}{l}22.91 \\
\%\end{array}$ & $19.43 \%$ & $\begin{array}{l}197 \\
1\end{array}$ & $\begin{array}{l}29.67 \\
\%\end{array}$ & $\begin{array}{l}24.24 \\
\%\end{array}$ & $19.58 \%$ & 635 & $\begin{array}{l}24.61 \\
\%\end{array}$ & $\begin{array}{l}20.69 \\
\%\end{array}$ & $\begin{array}{l}18.52 \\
\%\end{array}$ & $0.000^{* *}$ \\
\hline $\begin{array}{l}\text { Funding } \\
\text { fragility }\end{array}$ & $\begin{array}{l}246 \\
8\end{array}$ & $\begin{array}{l}15.91 \\
\%\end{array}$ & $8.11 \%$ & $21.56 \%$ & $\begin{array}{l}190 \\
4\end{array}$ & $\begin{array}{l}13.00 \\
\%\end{array}$ & $6.91 \%$ & $18.02 \%$ & 564 & $\begin{array}{l}25.88 \\
\%\end{array}$ & $\begin{array}{l}15.25 \\
\%\end{array}$ & $\begin{array}{l}28.61 \\
\%\end{array}$ & $0.000^{* *}$ \\
\hline $\log ($ Size $)$ & $\begin{array}{l}260 \\
6 \\
\end{array}$ & 7.48 & 8.70 & 4.66 & $\begin{array}{l}197 \\
1 \\
\end{array}$ & 7.61 & 8.81 & 4.44 & 635 & 7.11 & 8.17 & 5.20 & $0.001^{* *}$ \\
\hline $\begin{array}{l}\text { Other } \\
\text { earning } \\
\text { assets }\end{array}$ & $\begin{array}{l}254 \\
8\end{array}$ & $0.94 \%$ & $0.31 \%$ & $3.02 \%$ & $\begin{array}{l}192 \\
4\end{array}$ & $0.91 \%$ & $0.35 \%$ & $2.83 \%$ & 624 & $\begin{array}{l}1.05 \\
\%\end{array}$ & $0.20 \%$ & $\begin{array}{l}3.54 \\
\%\end{array}$ & $0.075^{\star}$ \\
\hline $\begin{array}{l}\text { Income } \\
\text { diversity }\end{array}$ & $\begin{array}{l}258 \\
4\end{array}$ & $\begin{array}{l}49.49 \\
\%\end{array}$ & $\begin{array}{l}39.44 \\
\%\end{array}$ & $\begin{array}{l}200.96 \\
\%\end{array}$ & $\begin{array}{l}195 \\
0\end{array}$ & $\begin{array}{l}41.74 \\
\%\end{array}$ & $\begin{array}{l}38.68 \\
\%\end{array}$ & $\begin{array}{l}222.06 \\
\%\end{array}$ & 634 & $\begin{array}{l}73.42 \\
\%\end{array}$ & $\begin{array}{l}45.48 \\
\%\end{array}$ & $\begin{array}{l}113.4 \\
2 \%\end{array}$ & $0.008^{* *}$ \\
\hline $\begin{array}{l}\text { Non-interest } \\
\text { income }\end{array}$ & $\begin{array}{l}258 \\
4\end{array}$ & $\begin{array}{l}38.19 \\
\%\end{array}$ & $\begin{array}{l}32.65 \\
\%\end{array}$ & $42.66 \%$ & $\begin{array}{l}195 \\
0\end{array}$ & $\begin{array}{l}36.51 \\
\%\end{array}$ & $\begin{array}{l}32.63 \\
\%\end{array}$ & $27.40 \%$ & 634 & $\begin{array}{l}43.44 \\
\%\end{array}$ & $\begin{array}{l}32.77 \\
\%\end{array}$ & $\begin{array}{l}71.42 \\
\%\end{array}$ & $0.038^{* *}$ \\
\hline $\begin{array}{l}\text { Equity } \\
\text { Volatility }\end{array}$ & $\begin{array}{l}131 \\
5\end{array}$ & $\begin{array}{l}2.44 \\
\%\end{array}$ & $\begin{array}{l}27.41 \\
\%\end{array}$ & $63.16 \%$ & $\begin{array}{l}101 \\
1\end{array}$ & $\begin{array}{l}45.45 \\
\%\end{array}$ & $\begin{array}{l}26.63 \\
\%\end{array}$ & $\begin{array}{l}105.90 \\
\%\end{array}$ & 304 & $\begin{array}{l}47.52 \\
\%\end{array}$ & $\begin{array}{l}34.31 \\
\%\end{array}$ & $\begin{array}{l}43.33 \\
\%\end{array}$ & $0.050^{* *}$ \\
\hline $\log Z$ & $\begin{array}{l}260 \\
3 \\
\end{array}$ & 2.19 & 2.87 & 1.57 & $\begin{array}{l}199 \\
1 \\
\end{array}$ & 2.32 & 3.00 & 1.56 & 612 & 1.75 & 2.48 & 1.53 & $0.001^{* *}$ \\
\hline
\end{tabular}




\begin{tabular}{|c|c|c|c|c|c|c|c|c|c|c|c|c|c|}
\hline \multicolumn{14}{|c|}{ Regulation and Institution } \\
\hline Official & 198 & 6.64 & 8.00 & 4.77 & 198 & 6.60 & 8.00 & 4.81 & 154 & 6.68 & 8.00 & 4.74 & $0.000^{* *}$ \\
\hline Capital & 198 & 4.38 & 5.50 & 3.11 & 198 & 4.29 & 5.00 & 3.11 & 154 & 4.47 & 6.00 & 3.11 & $0.000^{* *}$ \\
\hline Restrict & 198 & 6.10 & 8.00 & 4.45 & 198 & 6.01 & 8.00 & 4.48 & 154 & 6.18 & 8.00 & 4.43 & $0.000^{* *}$ \\
\hline $\begin{array}{l}\text { Private } \\
\text { Monitoring }\end{array}$ & 198 & 4.98 & 7.00 & 3.42 & 198 & 4.90 & 7.00 & 3.43 & 154 & 5.06 & 7.00 & 3.41 & 0.627 \\
\hline Institution & 198 & -0.42 & -0.25 & 0.33 & 198 & -0.43 & -0.27 & 0.31 & 154 & -0.41 & -0.23 & 0.35 & 0.909 \\
\hline State & $\begin{array}{l}340 \\
9\end{array}$ & \begin{tabular}{|l|}
18.75 \\
$\%$ \\
\end{tabular} & $0.00 \%$ & $39.03 \%$ & $\begin{array}{l}250 \\
7 \\
\end{array}$ & $\begin{array}{l}20.36 \\
\%\end{array}$ & $0.00 \%$ & $40.27 \%$ & 902 & $\begin{array}{l}16.56 \\
\%\end{array}$ & $0.00 \%$ & $\begin{array}{l}36.93 \\
\%\end{array}$ & 0.809 \\
\hline \multicolumn{14}{|c|}{ Corporate Governance } \\
\hline $\begin{array}{l}\text { Ownership } \\
\text { concentratio } \\
n\end{array}$ & $\begin{array}{l}180 \\
6\end{array}$ & \begin{tabular}{|l|}
51.98 \\
$\%$
\end{tabular} & $\begin{array}{l}49.00 \\
\%\end{array}$ & $30.22 \%$ & $\begin{array}{l}135 \\
4\end{array}$ & $\begin{array}{l}52.90 \\
\%\end{array}$ & $\begin{array}{l}50.00 \\
\%\end{array}$ & $29.62 \%$ & 452 & $\begin{array}{l}49.22 \\
\%\end{array}$ & $\begin{array}{l}40.66 \\
\%\end{array}$ & $\begin{array}{l}31.77 \\
\%\end{array}$ & 0.635 \\
\hline $\begin{array}{l}\text { Government } \\
\text { ownership }\end{array}$ & 403 & $\begin{array}{l}28.38 \\
\% \\
\end{array}$ & $\begin{array}{l}11.50 \\
\%\end{array}$ & $34.75 \%$ & 298 & $\begin{array}{l}27.84 \\
\%\end{array}$ & $\begin{array}{l}14.73 \\
\%\end{array}$ & $34.12 \%$ & 105 & $\begin{array}{l}29.96 \\
\%\end{array}$ & $\begin{array}{l}10.94 \\
\%\end{array}$ & $\begin{array}{l}36.44 \\
\%\end{array}$ & 0.108 \\
\hline $\begin{array}{l}\text { Foreign } \\
\text { ownership }\end{array}$ & $\begin{array}{l}102 \\
3\end{array}$ & \begin{tabular}{|l|}
42.06 \\
$\%$ \\
\end{tabular} & $\begin{array}{l}35.00 \\
\%\end{array}$ & $31.80 \%$ & 784 & $\begin{array}{l}43.10 \\
\%\end{array}$ & $\begin{array}{l}39.05 \\
\%\end{array}$ & $30.00 \%$ & 239 & $\begin{array}{l}38.64 \\
\%\end{array}$ & $\begin{array}{l}30.09 \\
\%\end{array}$ & $\begin{array}{l}36.88 \\
\%\end{array}$ & 0.489 \\
\hline \multicolumn{14}{|c|}{ Macroeconomic variables } \\
\hline $\log G D P$ & 209 & 9.55 & 10.74 & 3.67 & 209 & 9.67 & 10.80 & 3.52 & 154 & 9.44 & 10.68 & 3.82 & $0.000^{* *}$ \\
\hline $\begin{array}{l}\text { Current } \\
\text { Account }\end{array}$ & 209 & $5.11 \%$ & $2.07 \%$ & $16.27 \%$ & 209 & $5.59 \%$ & $3.04 \%$ & $15.60 \%$ & 154 & $\begin{array}{l}4.63 \\
\%\end{array}$ & $1.11 \%$ & $\begin{array}{l}16.95 \\
\% \\
\end{array}$ & $0.000^{\star *}$ \\
\hline $\begin{array}{l}\text { GDP } \\
\text { Growth }\end{array}$ & 209 & $4.24 \%$ & $3.75 \%$ & $7.18 \%$ & 209 & $4.06 \%$ & $3.80 \%$ & $7.39 \%$ & 154 & $\begin{array}{l}4.43 \\
\%\end{array}$ & $3.70 \%$ & $\begin{array}{l}6.97 \\
\%\end{array}$ & $0.000^{\star *}$ \\
\hline Inflation & 209 & $\begin{array}{l}- \\
5.22 \%\end{array}$ & $-3.17 \%$ & $7.71 \%$ & 209 & $4.93 \%$ & $-\overline{3.07 \%}$ & $7.34 \%$ & 154 & $\begin{array}{l}- \\
5.51 \\
\%\end{array}$ & $3.26 \%$ & $\begin{array}{l}8.08 \\
\%\end{array}$ & $0.000^{\star \star}$ \\
\hline \multicolumn{14}{|c|}{ Other Control Variables } \\
\hline $\begin{array}{l}\text { Political } \\
\text { Stability and } \\
\text { AV }\end{array}$ & 198 & $\begin{array}{l}69.55 \\
\%\end{array}$ & $\begin{array}{l}69.89 \\
\%\end{array}$ & $13.01 \%$ & 198 & $\begin{array}{l}69.55 \\
\%\end{array}$ & $\begin{array}{l}69.89 \\
\%\end{array}$ & $13.01 \%$ & 154 & $\begin{array}{l}70.40 \\
\%\end{array}$ & $\begin{array}{l}71.69 \\
\%\end{array}$ & $\begin{array}{l}13.10 \\
\%\end{array}$ & $0.000^{* *}$ \\
\hline $\begin{array}{l}\text { Regulatory } \\
\text { Quality }\end{array}$ & 198 & $\begin{array}{l}69.67 \\
\% \\
\end{array}$ & $\begin{array}{l}72.73 \\
\% \\
\end{array}$ & $18.40 \%$ & 198 & $\begin{array}{l}69.67 \\
\%\end{array}$ & $\begin{array}{l}72.73 \\
\%\end{array}$ & $18.40 \%$ & 154 & $\begin{array}{l}69.10 \\
\%\end{array}$ & $\begin{array}{l}68.18 \\
\% \\
\end{array}$ & $\begin{array}{l}20.13 \\
\%\end{array}$ & $0.002^{* *}$ \\
\hline Rule of Law & 198 & $\begin{array}{l}68.60 \\
\%\end{array}$ & $\begin{array}{l}66.67 \\
\%\end{array}$ & $17.34 \%$ & 198 & $\begin{array}{l}68.60 \\
\%\end{array}$ & $\begin{array}{l}66.67 \\
\%\end{array}$ & $17.34 \%$ & 154 & $\begin{array}{l}68.18 \\
\%\end{array}$ & $\begin{array}{l}66.67 \\
\%\end{array}$ & $\begin{array}{l}18.30 \\
\%\end{array}$ & 0.147 \\
\hline $\begin{array}{l}\text { Control of } \\
\text { Corruption }\end{array}$ & 198 & $\begin{array}{l}37.16 \\
\%\end{array}$ & $\begin{array}{l}33.33 \\
\%\end{array}$ & $12.10 \%$ & 198 & $\begin{array}{l}37.16 \\
\%\end{array}$ & $\begin{array}{l}33.33 \\
\%\end{array}$ & $12.10 \%$ & 154 & $\begin{array}{l}36.96 \\
\%\end{array}$ & $\begin{array}{l}33.33 \\
\%\end{array}$ & $\begin{array}{l}11.67 \\
\%\end{array}$ & $0.095^{*}$ \\
\hline
\end{tabular}

Source: Authors' calculations

\subsection{Bank-level characteristics, regulation and ownership}

Our sample includes CBs and IBs in 19 countries from the MENA region. ${ }^{7}$ Both banking sectors are required to follow national and international regulatory requirements under the supervision of the banking authorities of their host country, and both types of banks adhere to the same accounting standards (Alexakis and Tsikouras, 2009). Thus, the

\footnotetext{
${ }^{7}$ In this paper, we use the abbreviation CB to denote all conventional banks, rather than only commercial banks. Data for bank holding companies, cooperative banks, investment banks, microfinance institutions, multi-lateral government banks, central banks, real estate and mortgage banks, credit institutions, and investment and trust corporations are not included in our analysis because these specialized financial institutions often operate differently than full-service commercial and Islamic banks.
} 
data should be consistent across the two types of banks, but some discrepancy in their practices is also possible (for example, IBs must also conform to the requirements of the Shariah supervisory board). The choice of variables used in our analysis is guided by previous literature and data availability. These variables include a set of profitability ratios, asset composition measures, efficiency ratios, liquidity ratios, risk measures, and dummy variables that capture individual bank characteristics. All independent variables are described in Appendix A.

As mentioned above, Table 2 compares the bank-level characteristics between the samples of CBs and IBs. As proxies of bank efficiency we use CIR and NIM. Bank profitability is measured by EARTA and EARGL. Kosmidou et al. (2007) and Van Horen (2007) argue that earnings to total assets ratio (ROA) is the most useful measure of profitability overtime because assets have a direct impact on both income and expenses. However, our analysis includes all four measures described in Table 2. The only bank performance measure that is significantly different between CBs and IBs is EARGL; its mean value is negative over the observation period (2005-2015) and amounts to $-1.29 \%$ for CBs and $-1.00 \%$ for IBs. Bank cost efficiency ratios are not statistically different between the two samples; EARTA is negative for the whole sample, as well as for the sample of IBs (-0.40\%). As pointed out by Grassa (2012), Islamic profit-loss sharing products present greater insolvency risk than products offered by $\mathrm{CBs}$, and this type of risk has a more detrimental impact on bank performance during a prolonged crisis. In line with this finding, CBs seem to be more profitable than IBs (based on EARTA ratio) over the total sample period. Furthermore, CBs have higher level of cost efficiency as compared with IBs (47.29\% vs $49.65 \%)$. However, none of these ratios are statistically different between the two groups of banks.

Next, we compare the individual bank characteristics between the two samples of banks, and find that the bank-specific variables are significantly different between CBs and IBs (except net income to total assets ratio). Regarding the asset size, IBs are smaller than CBs, on average. However, they tend to have higher loans to total assets ratio, Tier 1 ratio, funding fragility, other earnings assets, and greater proportion of noninterest-bearing assets than CBs. These results are in line with Olson and Zoubi (2011) for the MENA region. Data in Table 2 show that IBs have much lower deposit to assets ratio $(69.54 \%$ vs. $79.17 \%)$ as well as tangible equity ratio (1.58\% vs. $19.67 \%)$. The data in Table 2 for the risk measures (equity volatility and distance to default or Z-score) show IBs to have, on average, higher level of risk than CBs. In line with our findings, Olson and Zoubi (2011) report that the Z-scores for IBs have fallen relative to CBs since 2008. In conclusion, although IBs and CBs have similar levels of profitability they are significantly different when different operating characteristics are taken into consideration as shown in Table 2. 
Table 2 also displays regulatory measures for the samples of CBs and IBs. We observe that official supervisory index, capital regulation and the restriction on bank activities are significantly different between the two groups of banks (the mean value is statistically significant at the $1 \%$ level of significance). However, these variables carry similar values across the two samples. Following the approach of Kaufmann et al. (2008), we create an index, which is the mean of six variables for each country in the sample, institution. ${ }^{8}$ A higher value of the index indicates better institutions. The median value of this index for the total sample of banks is negative $(-0.27)$, which indicates a very week institutional environment. The last variable to consider in our analysis is an indicator for state ownership, state. This variable takes value one if the state owns more than $10 \%$ of a bank, and zero otherwise. The data in Table 2 show that the level of state ownership in higher in CBs than in IBs (20.36\% vs. $16.56 \%)$.

Recent empirical literature emphasizes the importance of the nature of ownership for bank performance and risk taking. We also investigate the link between the type of ownership and bank performance. Following Haque and Brown (2017), we use three measures of ownership structure - ownership concentration, government ownership and foreign ownership. IBs are typically domestically owned and the data in Table 2 support this convention; the percentage of foreign ownership is much larger in CBs than in IBs (43.10\% vs. $38.64 \%)$. Ownership concentration is around $50 \%$ in both types of banks, while the share of government ownership is larger for IBs. None of the three variables is however, statistically different between the two samples. Finally, we present the following macroeconomic indicators - Gross domestic product (GDP) per capita (in log form), the ratio of current account balance to GDP, GDP growth, and inflation. All macroeconomic variables are significantly different between the two samples. Table 2 also includes information for additional control variables that measure the quality of institutions in a bank's home country - political stability and absence of violence (PS), regulatory quality $(R Q$, rule of law $(R L)$, and control of corruption $(C O C)$. Two of them ( $P S$ and $R Q$ ) are significantly different between the two groups; however, the difference in the level of corruption is only marginally significant.

To test our hypothesis that the performance of IBs and CBs can be different before, during and after the crisis, we also run our descriptive analysis separately for each type of banks using three time periods: pre-crisis (2005-2007), crisis (2008-2009) and postcrisis (2010-2015). The results are available upon request. The evidence shows that profitability as measured by EARTA, was negative for both CBs and IBs during the crisis

\footnotetext{
${ }^{8}$ As proxies for country-level governance, we use the country-level indicators of Kaufmann et al. (2008). These indicators are obtained from combining several hundred individual variables measuring political stability, government effectiveness, regulatory quality, enforcement of the rule of law, corruption, and the extent to which a country's citizens are able to participate in selecting their government.
} 
period $(-0.21 \%$ vs. $-0.13 \%)$, but shows as positive in the post-crisis period only in the group of CBs. We note that IBs had higher profitability and lower level of inefficiency (based on cost-to-income ratio) as compared to $\mathrm{CBs}$ during the pre-crisis and crisis periods. However, net interest margin for IBs continue to decrease in the post-crisis period, whereas cost inefficiency remains relatively high in the same period as compared to CBs $(51.66 \%$ vs. $47.02 \%)$. These findings are in line with our first hypothesis ( $\mathrm{H} 1$ ). In addition, funding fragility is higher for IBs than CBs, (about $50 \%$ more), especially during the crisis period. The data confirm our observation that IBs are riskier than CBs in general, but the probability of default of Islamic banks has decreased significantly after the year of 2009. The institutional environment remains weak before, during and after the crisis, that is, CBs and IBs are operating in countries that are still facing the negative consequences of the global financial crisis but IBs have needed more time to recover from the crisis.

\section{Empirical results and analysis}

\subsection{Empirical specification and preliminary tests}

A substantial body of literature has examined the variables that determine bank profitability and efficiency. Therefore, we first estimate the variables that are expected to be significant determinants of bank profitability and efficiency in the MENA region, and whether these determinants differ between CBs and IBs. We use an unbalanced dynamic panel model and employ the bank-level characteristics listed in Table 2 as independent variables as they may identify operational and profitability differences between CBs and IBs. The basic framework for our analysis is:

$$
f(C I R \mid \text { EARTA }) \text { it }=\alpha+\beta \times X_{i t}+\gamma \times Y_{i t}+\varphi \times Z_{i t}+\psi \times \text { Dummy }+\varepsilon_{i t},
$$

where $C I R$ and EARTA are respectively, cost efficiency and profitability of bank $i$ in year $t, \alpha$ is the common intercept across banks in the random effects model, $X_{i t}$ is a vector of explanatory variables (regulation and ownership), $Y_{i t}$ is a vector of interaction terms for ownership (ownership concentration, government and foreign ownership) and different proxies for regulation, $Z_{i t}$ is the vector of control variables (bank accounting ratios, risk measures, and macroeconomic indicators), $\beta, \gamma$ and $\varphi$ are vectors of regression coefficients, and $\varepsilon_{i t}$ is the disturbance term that is assumed to be normally distributed with a mean of zero. The vector of dummy variables includes an ISLAMIC dummy variable that equals one if a bank is Islamic, and a LISTED dummy variable that equals one if a bank is listed on a national or international stock exchange. We follow the work of Abedifar et al. (2013) and Beck et al. (2013) and consider 2008-2009 as the crisis period. Accordingly, we use a crisis time dummy (CRISIS) that takes the value of one 
for the years 2008-2009, and 0 otherwise. We also control for year and country fixed effects in each model. ${ }^{9}$

Olson and Zoubi (2011) find that bank profitability is determined by individual bankspecific characteristics such as the inefficiency ratio, capital strength, asset specialization ratios, and whether a bank is listed or unlisted. The paper concludes that the banking models across MENA countries are different, but profitability does not seem to be determined by whether a bank is an Islamic or a commercial bank. We run a number of preliminary tests to determine the specific bank-level characteristics that influence the performance of banks in the MENA region. The results are available upon request. We use as dependent variables CIR and EARTA. In support of the common view that traditional bank performance depends mostly on loans and deposits, we observe a positive and significant correlation between cost efficiency ratio and these two variables. Funding fragility, bank size, income diversity, non-interest income and risk taking are also significant determinants of a bank's efficiency. Ownership variables are not associated with cost efficiency individually but when regulatory variables are added to the model, foreign ownership does play a significant role in explaining bank efficiency. The results for bank profitability are quite similar.

An important finding of this analysis is that bank efficiency is strongly dependent on the type of the banking system - conventional or Islamic (the dummy variable for IBs is positive and strongly significant in all models). However, bank profitability does not seem to be determined by whether a bank is a CB or an IB. Furthermore, we find that banks are more cost efficient but less profitable when a bank is listed on a national or regional stock exchange. Finally, we observe a significant effect of the global financial crisis on bank performance in the MENA region.

\subsection{The effect of regulation and ownership on bank performance}

Given that bank regulation (and more particularly Basel II regulations) does not differentiate on bank ownership type, it is important to investigate whether the effect of regulation on bank efficiency and profitability depends on the type of ownership. To test this hypothesis, we introduce in equation (1) an interaction term between regulatory variables (official supervisory power, capital regulation, activity restrictions and private monitoring) and ownership indicator variables (concentration, government and foreign ownership). We expect regulatory measures to have a significant influence on the performance of banks in the MENA region. In addition, we hypothesize that ownership concentration and government ownership should have negative impact on a bank's cost

\footnotetext{
${ }^{9}$ We performed a Hausman test to determine whether to choose random-effect or fixed-effect models. The Hausman test rejects the fixed effects specification at the $1 \%$ level for all independent variables.
} 
efficiency, whereas foreign ownership effect should be positive. For bank profitability, these individual effects should be opposite. For the interaction variable, we expect that the effect of bank regulation may be different depending on bank ownership type, to the main results.

The outputs of the regression analysis for bank efficiency are reported in Table 3. In model 1 we estimate the individual effect of regulatory and ownership variables. Only the index of bank capital regulation seems to have a significant influence on cost efficiency. In line with prior literature, we find that better capital regulation is associated with an improved efficiency of a bank (the estimated coefficient of capital variable is negative and strongly significant). This is partially in line with hypothesis (3a): Capital regulation and official supervisory power should have a positive influence on bank efficiency. The rest of the regulatory variables are, however, insignificant. Although the ownership variables carry the correct sign, none of them is statistically significant. This contradicts our second hypothesis (H2a): "Government ownership should have a negative influence on bank efficiency; however, the effect of ownership concentration and foreign ownership on cost efficiency should be positive."

In line with previous findings (see Table 2), we find a negative association between the quality of institutions and a bank's cost efficiency. We also include bank-level characteristics, risk measures and macroeconomic variables determined in step one, and we find these variables to have a strong influence on bank efficiency. All dummy variables are strongly significant. In the next three models, we introduce an interaction term between regulatory variables and each ownership variable (see Models 2 to 4). We observe that both the official supervisory index and the interaction term between this index and each ownership variable are statistically significant. Individually, the increased level of official supervisory power has a negative influence of on a bank's cost efficiency but this effect is less pronounced for banks with higher level of ownership concentration, bigger share of government ownership or larger foreign presence. The positive impact of increased capital regulation on efficiency, however, does not depend on bank ownership type. As regulatory variables may be correlated with each other, in Models 5 to 8 , we introduce an interaction term between each regulatory variable and the ownership variables one at a time. We observe that individually all the regulatory measures (except capital regulation) have no influence on bank efficiency; however, when they are interacted with government ownership variable, this effect is strongly significant and leads to an improved cost efficiency. 
Table 3: Panel regressions of bank efficiency (All banks, 2005-2015)

\begin{tabular}{|c|c|c|c|c|c|c|c|c|}
\hline $\begin{array}{l}\text { Explanatory } \\
\text { Variables }\end{array}$ & Model 1 & Model 2 & Model 3 & Model 4 & Model 5 & Model 6 & Model 7 & Model 8 \\
\hline \multirow[t]{2}{*}{ Constant } & $0.251^{* * *}$ & $0.248^{* * *}$ & $0.252^{* * *}$ & $0.258^{* * *}$ & $0.252^{* *}$ & $0.255^{\star * *}$ & $0.253^{* * *}$ & $0.254^{\star \star \star}$ \\
\hline & $(0.000)$ & $(0.000)$ & $(0.000)$ & $(0.000)$ & $(0.000)$ & $(0.000)$ & $(0.000)$ & $(0.000)$ \\
\hline \multirow{2}{*}{ Official } & 0.002 & $0.005^{\star \star}$ & $0.003^{*}$ & $0.004^{\star}$ & 0.003 & 0.002 & 0.003 & 0.003 \\
\hline & $(0.189)$ & $(0.034)$ & $(0.092)$ & $(0.062)$ & $(0.158)$ & $(0.193)$ & $(0.177)$ & $(0.185)$ \\
\hline \multirow[t]{2}{*}{ Capital } & $-0.011^{* *}$ & $-0.015^{* * *}$ & $-0.011^{* *}$ & $-0.011^{* *}$ & $-0.011^{* * *}$ & $-0.012^{* * *}$ & $-0.011^{* * *}$ & $-0.011^{* *}$ \\
\hline & $(0.013)$ & $(0.005)$ & $(0.010)$ & $(0.017)$ & $(0.009)$ & $(0.008)$ & $(0.009)$ & $(0.013)$ \\
\hline \multirow[t]{2}{*}{ Restrict } & -0.001 & -0.001 & -0.001 & -0.001 & -0.001 & -0.001 & -0.001 & -0.001 \\
\hline & $(0.480)$ & $(0.741)$ & $(0.398)$ & $(0.511)$ & $(0.463)$ & $(0.466)$ & $(0.432)$ & $(0.495)$ \\
\hline \multirow{2}{*}{ Private Monitoring } & 0.002 & 0.001 & 0.003 & -0.000 & 0.003 & 0.003 & 0.003 & 0.001 \\
\hline & $(0.421)$ & $(0.804)$ & $(0.370)$ & $(0.993)$ & $(0.349)$ & $(0.348)$ & $(0.335)$ & $(0.566)$ \\
\hline \multirow[t]{2}{*}{ Ownership } & 0.008 & 0.004 & 0.008 & 0.009 & 0.007 & 0.001 & 0.008 & 0.004 \\
\hline & $(0.493)$ & $(0.816)$ & $(0.497)$ & $(0.454)$ & $(0.729)$ & $(0.952)$ & $(0.686)$ & $(0.832)$ \\
\hline \multirow[t]{2}{*}{ Government } & 0.027 & 0.034 & $0.081^{\star \star *}$ & 0.023 & $0.080^{* *}$ & $0.066^{\star \star}$ & $0.065^{\star \star}$ & $0.064^{* \star}$ \\
\hline & $(0.273)$ & $(0.179)$ & $(0.008)$ & $(0.364)$ & $(0.013)$ & $(0.036)$ & $(0.041)$ & $(0.044)$ \\
\hline \multirow[t]{2}{*}{ Foreign } & -0.020 & -0.022 & -0.021 & $-0.053^{\star \star}$ & -0.032 & $-0.045^{*}$ & $-0.040^{*}$ & $-0.052^{* *}$ \\
\hline & $(0.230)$ & $(0.186)$ & $(0.212)$ & $(0.028)$ & $(0.210)$ & $(0.082)$ & $(0.121)$ & $(0.047)$ \\
\hline \multirow[t]{2}{*}{ Official $\times O C$} & & $-0.010^{*}$ & & & 0.000 & & & \\
\hline & & $(0.062)$ & & & $(0.916)$ & & & \\
\hline \multirow[t]{2}{*}{ Capital $\times$ OC } & & 0.014 & & & & 0.001 & & \\
\hline & & $(0.154)$ & & & & (0.634) & & \\
\hline \multirow[t]{2}{*}{ Restrict $x O C$} & & -0.001 & & & & & 0.000 & \\
\hline & & $(0.754)$ & & & & & $(0.958)$ & \\
\hline \multirow[t]{2}{*}{ Priv Monitor x OC } & & 0.005 & & & & & & 0.001 \\
\hline & & $(0.505)$ & & & & & & $(0.772)$ \\
\hline \multirow[t]{2}{*}{ Official $x$ GO } & & & $-0.026^{* *}$ & & $-0.014^{* * *}$ & & & \\
\hline & & & $(0.024)$ & & $(0.004)$ & & & \\
\hline \multirow[t]{2}{*}{ Capital x GO } & & & 0.002 & & & $-0.021^{* *}$ & & \\
\hline & & & $(0.937)$ & & & $(0.021)$ & & \\
\hline \multirow[t]{2}{*}{ Restrict x GO } & & & 0.025 & & & & $-0.013^{\star *}$ & \\
\hline & & & $(0.313)$ & & & & $(0.024)$ & \\
\hline \multirow[t]{2}{*}{ Priv Monitor x GO } & & & -0.014 & & & & & $-0.016^{* *}$ \\
\hline & & & $(0.689)$ & & & & & $(0.027)$ \\
\hline \multirow[t]{2}{*}{ Official $x F O$} & & & & $-0.013^{*}$ & 0.002 & & & \\
\hline & & & & $(0.101)$ & $(0.530)$ & & & \\
\hline \multirow[t]{2}{*}{ Capital x FO } & & & & 0.011 & & 0.006 & & \\
\hline & & & & $(0.464)$ & & $(0.191)$ & & \\
\hline \multirow[t]{2}{*}{ Restrict $x F O$} & & & & -0.001 & & & 0.003 & \\
\hline & & & & $(0.864)$ & & & $(0.299)$ & \\
\hline \multirow[t]{2}{*}{ Priv Monitor $x$ FO } & & & & $0.018^{*}$ & & & & 0.007 \\
\hline & & & & $(0.094)$ & & & & $(0.102)$ \\
\hline Institution & $0.063^{* *}$ & $0.070^{\star *}$ & $0.061^{* *}$ & $0.067^{\star *}$ & $0.063^{* *}$ & $0.063^{* *}$ & $0.064^{* *}$ & $0.064^{* *}$ \\
\hline & $(0.024)$ & $(0.013)$ & $(0.029)$ & $(0.018)$ & $(0.025)$ & $(0.024)$ & $(0.023)$ & $(0.023)$ \\
\hline ISLAMIC_D & $0.057^{* * *}$ & $0.057^{* * *}$ & $0.056^{* * *}$ & $0.058^{* * *}$ & $0.056^{* * *}$ & $0.056^{* * *}$ & $0.056^{* * *}$ & $0.057^{\star * \star}$ \\
\hline & $(0.000)$ & $(0.000)$ & $(0.000)$ & $(0.000)$ & $(0.000)$ & $(0.000)$ & $(0.000)$ & $(0.000)$ \\
\hline LISTED_D & $-0.027^{* * *}$ & $-0.027^{* * *}$ & $-0.026^{* * *}$ & $-0.027^{* * *}$ & $-0.026^{* * *}$ & $-0.026^{* * *}$ & $-0.026^{* * *}$ & $-0.026^{* * *}$ \\
\hline & $(0.002)$ & $(0.002)$ & $(0.003)$ & $(0.002)$ & $(0.003)$ & $(0.002)$ & $(0.003)$ & $(0.003)$ \\
\hline CRISIS D & $-0.020^{* *}$ & $-0.020^{* *}$ & $-0.021^{* *}$ & $-0.020^{* *}$ & $-0.021^{* *}$ & $-0.021^{* *}$ & $-0.021^{* *}$ & $-0.021^{* *}$ \\
\hline & $(0.036)$ & $(0.035)$ & $(0.030)$ & $(0.038)$ & $(0.028)$ & $(0.029)$ & $(0.029)$ & $(0.028)$ \\
\hline $\begin{array}{l}\text { Bank } \\
\text { characteristics }\end{array}$ & Yes & Yes & Yes & Yes & Yes & Yes & Yes & Yes \\
\hline
\end{tabular}




\begin{tabular}{|l|c|c|c|c|c|c|c|c|}
\hline $\begin{array}{l}\text { Macroeconomic } \\
\text { factors }\end{array}$ & Yes & Yes & Yes & Yes & Yes & Yes & Yes & Yes \\
\hline Country Dummy & Yes & Yes & Yes & Yes & Yes & Yes & Yes & Yes \\
\hline $\begin{array}{l}\text { Number of } \\
\text { Observations }\end{array}$ & 3409 & 3409 & 3409 & 3409 & 3409 & 3409 & 3409 & 3409 \\
\hline $\begin{array}{l}R \text {-squared } \\
\text { (Overall) }\end{array}$ & 0.5123 & 0.5132 & 0.5139 & 0.5136 & 0.5138 & 0.5136 & 0.5134 & 0.5137 \\
\hline
\end{tabular}

Source: Authors' calculations

Table 4: Panel regressions of bank profitability (All banks, 2005-2015)

\begin{tabular}{|c|c|c|c|c|c|c|c|c|}
\hline $\begin{array}{l}\text { Explanatory } \\
\text { Variables }\end{array}$ & Model 1 & Model 2 & Model 3 & Model 4 & Model 5 & Model 6 & Model 7 & Model 8 \\
\hline \multirow[t]{2}{*}{ Constant } & $0.169^{\star \star \star}$ & $0.169^{\star \star \star}$ & $0.172^{\star \star \star}$ & $0.177^{\star \star \star}$ & $0.174^{* *}$ & $0.174^{\star \star \star}$ & $0.176^{\star * \star}$ & $0.171^{\star \star \star}$ \\
\hline & $(0.001)$ & $(0.001)$ & $(0.001)$ & $(0.001)$ & $(0.001)$ & $(0.001)$ & $(0.001)$ & $(0.001)$ \\
\hline \multirow{2}{*}{ Official } & $-0.007^{* *}$ & $-0.006^{*}$ & $-0.008^{* *}$ & $-0.007^{* *}$ & $-0.009^{* * *}$ & $-0.007^{* *}$ & $-0.008^{* *}$ & $-0.007^{* *}$ \\
\hline & $(0.010)$ & $(0.055)$ & $(0.010)$ & $(0.019)$ & $(0.003)$ & $(0.010)$ & $(0.009)$ & $(0.009)$ \\
\hline \multirow[t]{2}{*}{ Capital } & $-0.010^{*}$ & -0.005 & -0.008 & $-0.011^{*}$ & -0.009 & $-0.012^{* *}$ & -0.010 & -0.009 \\
\hline & $(0.102)$ & $(0.447)$ & $(0.156)$ & $(0.072)$ & $(0.105)$ & $(0.044)$ & $(0.102)$ & $(0.119)$ \\
\hline \multirow[t]{2}{*}{ Restrict } & $0.007^{\star *}$ & $0.008^{* *}$ & $0.007^{* *}$ & $0.007^{* *}$ & $0.007^{* *}$ & $0.007^{* *}$ & $0.006^{* *}$ & $0.008^{* * *}$ \\
\hline & $(0.011)$ & $(0.022)$ & $(0.015)$ & $(0.034)$ & $(0.011)$ & $(0.011)$ & $(0.047)$ & $(0.009)$ \\
\hline \multirow[t]{2}{*}{ Private Monitoring } & 0.006 & 0.001 & 0.005 & 0.007 & 0.006 & 0.006 & 0.006 & 0.003 \\
\hline & $(0.162)$ & $(0.742)$ & $(0.204)$ & $(0.133)$ & $(0.152)$ & $(0.148)$ & $(0.151)$ & $(0.490)$ \\
\hline \multirow[t]{2}{*}{ Ownership } & 0.002 & $-0.044^{*}$ & 0.002 & 0.003 & -0.020 & -0.024 & -0.021 & $-0.047^{*}$ \\
\hline & $(0.887)$ & $(0.081)$ & $(0.903)$ & $(0.828)$ & $(0.446)$ & $(0.363)$ & $(0.423)$ & $(0.083)$ \\
\hline \multirow[t]{2}{*}{ Government } & -0.046 & -0.031 & -0.058 & -0.050 & -0.049 & -0.040 & -0.050 & -0.029 \\
\hline & $(0.169)$ & $(0.355)$ & $(0.161)$ & $(0.138)$ & $(0.259)$ & $(0.342)$ & $(0.238)$ & $(0.496)$ \\
\hline \multirow[t]{2}{*}{ Foreign } & -0.023 & -0.019 & -0.023 & $-0.064^{*}$ & -0.046 & -0.047 & -0.050 & -0.025 \\
\hline & $(0.303)$ & $(0.401)$ & $(0.309)$ & $(0.050)$ & $(0.188)$ & $(0.177)$ & $(0.152)$ & $(0.477)$ \\
\hline \multirow[t]{2}{*}{ Official $x O C$} & & -0.004 & & & 0.003 & & & \\
\hline & & $(0.579)$ & & & $(0.252)$ & & & \\
\hline \multirow[t]{2}{*}{ Capital $\times O C$} & & -0.014 & & & & 0.007 & & \\
\hline & & $(0.276)$ & & & & $(0.176)$ & & \\
\hline \multirow[t]{2}{*}{ Restrict $x O C$} & & -0.000 & & & & & 0.004 & \\
\hline & & $(0.988)$ & & & & & $(0.212)$ & \\
\hline \multirow[t]{2}{*}{ Priv Monitor x OC } & & $0.030^{* *}$ & & & & & & $0.011^{* *}$ \\
\hline & & $(0.011)$ & & & & & & $(0.017)$ \\
\hline \multirow[t]{2}{*}{ Official $x$ GO } & & & -0.000 & & 0.001 & & & \\
\hline & & & $(0.950)$ & & $(0.772)$ & & & \\
\hline \multirow[t]{2}{*}{ Capital x GO } & & & -0.044 & & & 0.000 & & \\
\hline & & & $(0.352)$ & & & $(0.973)$ & & \\
\hline \multirow[t]{2}{*}{ Restrict $x$ GO } & & & 0.022 & & & & 0.003 & \\
\hline & & & $(0.515)$ & & & & $(0.685)$ & \\
\hline \multirow[t]{2}{*}{ Priv Monitor $x$ GO } & & & 0.012 & & & & & 0.000 \\
\hline & & & $(0.788)$ & & & & & $(0.928)$ \\
\hline \multirow[t]{2}{*}{ Official $x$ FO } & & & & -0.001 & 0.004 & & & \\
\hline & & & & $(0.863)$ & $(0.323)$ & & & \\
\hline \multirow[t]{2}{*}{ Capital x FO } & & & & 0.011 & & 0.006 & & \\
\hline & & & & $(0.573)$ & & $(0.322)$ & & \\
\hline \multirow[t]{2}{*}{ Restrict $x$ FO } & & & & 0.007 & & & 0.005 & \\
\hline & & & & $(0.547)$ & & & $(0.249)$ & \\
\hline \multirow[t]{2}{*}{ Priv Monitor x GO } & & & & -0.007 & & & & 0.001 \\
\hline & & & & $(0.622)$ & & & & $(0.816)$ \\
\hline
\end{tabular}




\begin{tabular}{|c|c|c|c|c|c|c|c|c|}
\hline Institution & $-0.086^{* *}$ & $-0.082^{* *}$ & $-0.090^{* *}$ & $-0.086^{* *}$ & $-0.087^{* *}$ & $-0.083^{* *}$ & $-0.087^{* *}$ & $-0.083^{* *}$ \\
\hline & $(0.022)$ & $(0.031)$ & $(0.018)$ & $(0.023)$ & $(0.021)$ & $(0.028)$ & $(0.021)$ & $(0.029)$ \\
\hline ISLAMIC_D & 0.007 & 0.007 & 0.007 & 0.007 & 0.007 & 0.007 & 0.007 & 0.007 \\
\hline & (0.589) & $(0.566)$ & $(0.606)$ & $(0.590)$ & $(0.570)$ & $(0.581)$ & $(0.588)$ & $(0.584)$ \\
\hline LISTED_D & $-0.028^{\star *}$ & $-0.029^{* *}$ & $-0.029^{* *}$ & $-0.029^{* *}$ & $-0.029^{* *}$ & $-0.029^{\star *}$ & $-0.029^{* *}$ & $-0.029^{* *}$ \\
\hline & $(0.016)$ & $(0.013)$ & $(0.014)$ & $(0.012)$ & $(0.013)$ & $(0.014)$ & $(0.012)$ & $(0.014)$ \\
\hline CRISIS_D & $-0.021 *$ & -0.020 & -0.021 & $-0.021 *$ & $--0.021 *$ & $-0.021 *$ & $-0.021 *$ & $-0.020 *$ \\
\hline & $(0.101)$ & $(0.116)$ & $(0.106)$ & $(0.098)$ & $(0.103)$ & $(0.102)$ & $(0.108)$ & $(0.110)$ \\
\hline $\begin{array}{l}\text { Bank } \\
\text { characteristics }\end{array}$ & Yes & Yes & Yes & Yes & Yes & Yes & Yes & Yes \\
\hline $\begin{array}{l}\text { Macroeconomic } \\
\text { factors }\end{array}$ & Yes & Yes & Yes & Yes & Yes & Yes & Yes & Yes \\
\hline Country Dummy & Yes & Yes & Yes & Yes & Yes & Yes & Yes & Yes \\
\hline $\begin{array}{l}\text { Number of } \\
\text { Observations }\end{array}$ & 3409 & 3409 & 3409 & 3409 & 3409 & 3409 & 3409 & 3409 \\
\hline$R$-squared (Overall) & 0.0901 & 0.0931 & 0.0905 & 0.0912 & 0.0914 & 0.0915 & 0.0917 & 0.0924 \\
\hline
\end{tabular}

Source: Authors' calculations

In line with our second hypothesis, foreign ownership has a positive influence on bank efficiency; however, we do not find evidence that this effect is correlated with bank regulations (all interaction terms with the regulatory measures are statistically insignificant). As expected, bank-level characteristics such as deposits, loans, bank size, income diversity and non-interest income are important determinants of bank efficiency. Low level of risk (as measured by higher distance to default) is associated with an improved bank's cost efficiency. The effects of whether a bank is an Islamic or a $\mathrm{CB}$, or the bank is listed or not on a national or international stock exchange, are also significant in all models. The evidence shows that banks in the MENA region had achieved higher efficiency during the crisis than in other time periods.

Table 4 reports the outputs from regressions of bank profitability. Our results are different from those reported in a similar study by Haque and Brown (2017). We find that all the regulatory measures (except private monitoring) have a strong influence on bank profitability. More specifically, capital regulation and official supervisory power have a negative impact on a bank's profitability, whereas restrictions on bank activities are positively associated with bank performance. This result is in line with our third hypothesis (H3b). However, none of the ownership variables is significant. This result contradicts our second hypothesis (H2b): "Government ownership should exert a positive influence on bank profitability; however, the effect of ownership concentration and foreign ownership on bank profitability should be negative". Next, we introduce an interaction term between regulatory measures and each ownership variable. Surprisingly, the interaction effect of regulation and ownership on bank profitability is insignificant in all models. There is limited evidence that the positive impact of regulatory empowerment of private monitoring on a bank's profitability is significant only for the banks with higher level of ownership concentration (see Models 2 and 8). A 
better quality of institutions is associated with poorer performance of banks in the respective country. In line with Olson and Zoubi (2011), the profitability does not seem to be determined by whether a bank is an Islamic or a commercial bank; however, private banks seem to be more profitable. As expected, banks are less profitable during the crisis periods.

The results reported in Tables 3 and 4 do not answer the question of whether the impact of regulation and ownership on bank efficiency and profitability is significantly different between Islamic and CBs. To the best of our knowledge this is the only study to have addressed this important question. It is also worth to investigate the reasons of such differences. Therefore, we run our analysis separately for the sample of CBs and the sample of IBs. In the next two tables, we report our results for bank efficiency for each type of banks. We do not find evidence of a significant influence of regulatory measures on the cost efficiency of a CB (see Table 5).

Table 5: Panel regressions of bank efficiency (Conventional banks, 2005-2015)

\begin{tabular}{|c|c|c|c|c|c|c|c|c|}
\hline $\begin{array}{l}\text { Explanatory } \\
\text { Variables }\end{array}$ & Model 1 & Model 2 & Model 3 & Model 4 & Model 5 & Model 6 & Model 7 & Model 8 \\
\hline \multirow[t]{2}{*}{ Constant } & $0.228^{\star \star \star}$ & $0.227^{\star \star \star}$ & $0.229^{\star \star \star}$ & $0.241^{\star * *}$ & $0.229^{\star * *}$ & $0.234^{* * *}$ & $0.231^{* * *}$ & $0.234^{\star \star *}$ \\
\hline & $(0.000)$ & $(0.000)$ & $(0.000)$ & $(0.000)$ & $(0.000)$ & $(0.000)$ & $(0.000)$ & $(0.000)$ \\
\hline \multirow[t]{2}{*}{ Official } & 0.000 & 0.003 & 0.002 & 0.003 & 0.001 & 0.001 & 0.001 & 0.001 \\
\hline & $(0.772)$ & $(0.210)$ & $(0.412)$ & $(0.269)$ & $(0.569)$ & $(0.772)$ & $(0.699)$ & $(0.730)$ \\
\hline \multirow[t]{2}{*}{ Capital } & -0.002 & $-0.012^{* *}$ & -0.004 & -0.004 & -0.003 & -0.003 & -0.003 & -0.002 \\
\hline & $(0.581)$ & $(0.042)$ & $(0.418)$ & $(0.374)$ & $(0.466)$ & $(0.456)$ & $(0.487)$ & $(0.591)$ \\
\hline \multirow{2}{*}{ Restrict } & 0.000 & 0.000 & 0.000 & 0.000 & 0.000 & 0.000 & 0.000 & 0.000 \\
\hline & $(0.917)$ & $(0.736)$ & $(0.985)$ & $(0.985)$ & $(0.959)$ & $(0.954)$ & $(0.959)$ & $(0.948)$ \\
\hline \multirow[t]{2}{*}{ Private Monitoring } & -0.003 & -0.000 & -0.002 & -0.005 & -0.002 & -0.002 & -0.002 & -0.003 \\
\hline & $(0.411)$ & $(0.980)$ & $(0.530)$ & $(0.203)$ & $(0.529)$ & $(0.505)$ & $(0.545)$ & $(0.398)$ \\
\hline \multirow[t]{2}{*}{ Ownership } & 0.011 & 0.012 & 0.013 & 0.010 & 0.010 & 0.004 & 0.015 & 0.019 \\
\hline & $(0.450)$ & $(0.560)$ & $(0.381)$ & $(0.479)$ & $(0.650)$ & $(0.840)$ & $(0.494)$ & $(0.415)$ \\
\hline \multirow{2}{*}{ Government } & 0.040 & $0.050^{*}$ & $0.138^{* * *}$ & 0.034 & $0.140^{* * *}$ & $0.103^{* * *}$ & $0.113^{* * *}$ & $0.100^{* *}$ \\
\hline & $(0.174)$ & $(0.093)$ & $(0.000)$ & $(0.241)$ & $(0.001)$ & $(0.007)$ & $(0.004)$ & $(0.010)$ \\
\hline \multirow[t]{2}{*}{ Foreign } & -0.016 & -0.019 & -0.017 & $-0.051^{* *}$ & -0.025 & $-0.045^{\star}$ & -0.038 & $-0.055^{\star}$ \\
\hline & $(0.390)$ & $(0.304)$ & $(0.358)$ & $(0.049)$ & $(0.370)$ & $(0.106)$ & $(0.166)$ & $(0.052)$ \\
\hline \multirow[t]{2}{*}{ Official $\times O C$} & & $-0.010^{*}$ & & & 0.000 & & & \\
\hline & & $(0.094)$ & & & $(0.897)$ & & & \\
\hline \multirow[t]{2}{*}{ Capital $\times O C$} & & $0.032^{\star * *}$ & & & & 0.001 & & \\
\hline & & $(0.005)$ & & & & $(0.688)$ & & \\
\hline \multirow[t]{2}{*}{ Restrict $x O C$} & & -0.002 & & & & & -0.001 & \\
\hline & & $(0.694)$ & & & & & $(0.858)$ & \\
\hline \multirow[t]{2}{*}{ Priv Monitor x OC } & & -0.010 & & & & & & -0.001 \\
\hline & & $(0.309)$ & & & & & & $(0.699)$ \\
\hline \multirow[t]{2}{*}{ Official $x$ GO } & & & $-0.029^{* *}$ & & $-0.021^{* * *}$ & & & \\
\hline & & & $(0.016)$ & & $(0.000)$ & & & \\
\hline \multirow[t]{2}{*}{ Capital x GO } & & & 0.016 & & & $-0.029^{* * *}$ & & \\
\hline & & & $(0.659)$ & & & $(0.005)$ & & \\
\hline \multirow[t]{2}{*}{ Restrict x GO } & & & 0.006 & & & & $-0.020^{* * *}$ & \\
\hline & & & $(0.809)$ & & & & $(0.002)$ & \\
\hline Priv Monitor $x$ GO & & & -0.006 & & & & & $-0.022^{\star \star \star}$ \\
\hline
\end{tabular}




\begin{tabular}{|l|c|c|c|c|c|c|c|c|}
\hline & & & $(0.862)$ & & & & & \\
\hline & & & & $-0.019^{* *}$ & 0.001 & & & \\
\hline Official $x$ FO & & & & $(0.041)$ & $(0.683)$ & & & \\
\hline Capital $x$ FO & & & & $0.028^{*}$ & & 0.008 & & \\
\hline & & & & $(0.095)$ & & $(0.152)$ & & \\
\hline Restrict $x$ FO & & & & -0.002 & & & 0.004 & \\
\hline & & & & $(0.821)$ & & & $(0.276)$ & \\
\hline Priv Monitor $x$ GO & & & & 0.013 & & & & $0.010^{*}$ \\
\hline & & & & $(0.269)$ & & & & $(0.065)$ \\
\hline Institution & $0.068^{* *}$ & $0.077^{* *}$ & $0.068^{* *}$ & $0.078^{* *}$ & $0.068^{* *}$ & $0.068^{* *}$ & $0.069^{* *}$ & $0.068^{* *}$ \\
\hline & $(0.043)$ & $(0.023)$ & $(0.043)$ & $(0.022)$ & $(0.045)$ & $(0.045)$ & $(0.040)$ & $(0.044)$ \\
\hline LISTED_D & -0.016 & -0.016 & -0.015 & -0.018 & -0.015 & -0.016 & -0.016 & -0.016 \\
\hline & $(0.123)$ & $(0.127)$ & $(0.153)$ & $(0.100)$ & $(0.150)$ & $(0.128)$ & $(0.143)$ & $(0.141)$ \\
\hline CRISIS_D & -0.014 & -0.014 & -0.014 & -0.013 & -0.014 & -0.014 & -0.014 & -0.015 \\
\hline & $(0.193)$ & $(0.197)$ & $(0.202)$ & $(0.221)$ & $(0.195)$ & $(0.187)$ & $(0.184)$ & $(0.175)$ \\
\hline $\begin{array}{l}\text { Bank } \\
\text { characteristics }\end{array}$ & Yes & Yes & Yes & Yes & Yes & Yes & Yes & Yes \\
\hline $\begin{array}{l}\text { Macroeconomic } \\
\text { factors }\end{array}$ & Yes & Yes & Yes & Yes & Yes & Yes & Yes & Yes \\
\hline Country Dummy & Yes & Yes & Yes & Yes & Yes & Yes & Yes & Yes \\
\hline $\begin{array}{l}\text { Number of } \\
\text { Observations }\end{array}$ & 2507 & 2507 & 2507 & 2507 & 2507 & 2507 & 2507 & 2507 \\
\hline $\begin{array}{l}R \text {-squared } \\
\text { (Overall) }\end{array}$ & 0.5104 & 0.5123 & 0.5140 & 0.5128 & 0.5139 & 0.5130 & 0.5130 & 0.5132 \\
\hline
\end{tabular}

Source: Authors' calculations

Table 6: Panel regressions of bank efficiency (Islamic banks, 2005-2015)

\begin{tabular}{|c|c|c|c|c|c|c|c|c|}
\hline $\begin{array}{l}\text { Explanatory } \\
\text { Variables }\end{array}$ & Model 1 & Model 2 & Model 3 & Model 4 & Model 5 & Model 6 & Model 7 & Model 8 \\
\hline \multirow[t]{2}{*}{ Constant } & $0.213^{\star \star \star}$ & $0.221^{\star \star \star}$ & $0.225^{\star \star \star}$ & $0.246^{\star \star \star}$ & $0.250^{\star \star \star}$ & $0.230^{\star \star \star}$ & $0.237^{\star \star}$ & $0.263^{\star \star *}$ \\
\hline & $(0.006)$ & $(0.006)$ & $(0.004)$ & $(0.002)$ & $(0.002)$ & $(0.005)$ & $(0.004)$ & $(0.001)$ \\
\hline \multirow{2}{*}{ Official } & $0.011^{* *}$ & $0.012^{* *}$ & $0.012^{* \star}$ & $0.008^{*}$ & $0.010^{* *}$ & $0.011^{* *}$ & $0.011^{* *}$ & $0.011^{* *}$ \\
\hline & $(0.015)$ & $(0.030)$ & $(0.010)$ & $(0.103)$ & $(0.033)$ & $(0.015)$ & $(0.013)$ & $(0.014)$ \\
\hline \multirow[t]{2}{*}{ Capital } & $-0.032^{* * *}$ & -0.015 & $-0.029^{* * *}$ & $-0.026^{* *}$ & $-0.031^{* * *}$ & $-0.032^{* * *}$ & $-0.031^{* * *}$ & $-0.030^{* * *}$ \\
\hline & $(0.001)$ & $(0.187)$ & $(0.003)$ & $(0.012)$ & $(0.001)$ & $(0.001)$ & $(0.001)$ & $(0.002)$ \\
\hline \multirow[t]{2}{*}{ Restrict } & $-0.013^{* *}$ & $-0.016^{* *}$ & $-0.016^{* * *}$ & -0.009 & $-0.013^{* *}$ & $-0.013^{* *}$ & $-0.015^{\star *}$ & $-0.013^{* *}$ \\
\hline & $(0.029)$ & $(0.037)$ & $(0.007)$ & $(0.166)$ & $(0.025)$ & $(0.026)$ & $(0.015)$ & $(0.025)$ \\
\hline \multirow{2}{*}{ Private Monitoring } & $0.020^{* * *}$ & $0.009^{* *}$ & $0.020^{* * *}$ & $0.013^{* *}$ & $0.020^{* * *}$ & $0.020^{* * *}$ & $0.020^{* * *}$ & $0.017^{\star * *}$ \\
\hline & $(0.001)$ & $(0.017)$ & $(0.001)$ & $(0.044)$ & $(0.001)$ & $(0.001)$ & $(0.001)$ & $(0.007)$ \\
\hline \multirow[t]{2}{*}{ Ownership } & -0.017 & -0.054 & -0.021 & -0.014 & -0.021 & -0.016 & -0.034 & -0.043 \\
\hline & $(0.498)$ & $(0.184)$ & $(0.407)$ & $(0.574)$ & $(0.612)$ & $(0.694)$ & $(0.403)$ & $(0.305)$ \\
\hline \multirow[t]{2}{*}{ Government } & -0.000 & 0.021 & -0.003 & -0.002 & -0.004 & -0.001 & 0.000 & 0.011 \\
\hline & $(0.995)$ & $(0.681)$ & $(0.950)$ & $(0.959)$ & $(0.933)$ & $(0.989)$ & $(0.999)$ & $(0.838)$ \\
\hline \multirow[t]{2}{*}{ Foreign } & -0.025 & -0.015 & -0.033 & -0.111 & -0.104 & -0.066 & -0.053 & -0.105 \\
\hline & $(0.503)$ & $(0.680)$ & $(0.394)$ & $(0.109)$ & $(0.136)$ & $(0.338)$ & $(0.442)$ & $(0.139)$ \\
\hline \multirow[t]{2}{*}{ Official $\times O C$} & & 0.005 & & & 0.001 & & & \\
\hline & & $(0.719)$ & & & $(0.804)$ & & & \\
\hline \multirow[t]{2}{*}{ Capital $\times$ OC } & & $-0.064^{* *}$ & & & & 0.000 & & \\
\hline & & $(0.010)$ & & & & $(0.985)$ & & \\
\hline \multirow[t]{2}{*}{ Restrict $x O C$} & & 0.013 & & & & & 0.003 & \\
\hline & & $(0.378)$ & & & & & $(0.519)$ & \\
\hline Priv Monitor $x O C$ & & $0.038^{\star *}$ & & & & & & 0.006 \\
\hline
\end{tabular}




\begin{tabular}{|c|c|c|c|c|c|c|c|c|}
\hline & & $(0.015)$ & & & & & & $(0.352)$ \\
\hline \multirow[t]{2}{*}{ Official x GO } & & & -0.022 & & 0.005 & & & \\
\hline & & & $(0.658)$ & & $(0.706)$ & & & \\
\hline \multirow[t]{2}{*}{ Capital x GO } & & & 0.091 & & & -0.001 & & \\
\hline & & & $(0.534)$ & & & $0.947)$ & & \\
\hline \multirow[t]{2}{*}{ Restrict x GO } & & & $0.322^{\star *}$ & & & & 0.010 & \\
\hline & & & $(0.028)$ & & & & $(0.506)$ & \\
\hline \multirow[t]{2}{*}{ Priv Monitor $x$ GO } & & & -0.416 & & & & & 0.004 \\
\hline & & & $(0.107)$ & & & & & $(0.801)$ \\
\hline \multirow[t]{2}{*}{ Official x FO } & & & & 0.027 & 0.011 & & & \\
\hline & & & & $(0.214)$ & $(0.168)$ & & & \\
\hline \multirow[t]{2}{*}{ Capital x FO } & & & & -0.047 & & 0.008 & & \\
\hline & & & & $(0.151)$ & & $(0.477)$ & & \\
\hline \multirow[t]{2}{*}{ Restrict $x F O$} & & & & -0.027 & & & 0.004 & \\
\hline & & & & $(0.254)$ & & & $(0.606)$ & \\
\hline \multirow[t]{2}{*}{ Priv Monitor x GO } & & & & $0.056^{\star *}$ & & & & 0.015 \\
\hline & & & & $(0.050)$ & & & & $(0.163)$ \\
\hline \multirow[t]{2}{*}{ Institution } & $0.098^{*}$ & 0.089 & $0.107^{*}$ & $0.099^{*}$ & $0.100^{*}$ & $0.098^{*}$ & $0.102^{*}$ & $0.104^{*}$ \\
\hline & $(0.091)$ & $(0.125)$ & $(0.064)$ & $(0.087)$ & $(0.084)$ & $(0.092)$ & $(0.080)$ & $(0.074)$ \\
\hline \multirow[t]{2}{*}{ LISTED_D } & $-0.046^{* * *}$ & $-0.045^{\star * *}$ & $-0.049^{* * *}$ & $-0.046^{\star \star *}$ & $-0.047^{\star \star *}$ & $-0.046^{\star \star *}$ & $-0.047^{\star * *}$ & $-0.047^{* *}$ \\
\hline & $(0.004)$ & $(0.004)$ & $(0.002)$ & $(0.004)$ & $(0.004)$ & $(0.004)$ & $(0.003)$ & $(0.003)$ \\
\hline \multirow[t]{2}{*}{ CRISIS_D } & $-0.033^{*}$ & $-0.027^{*}$ & $-0.034^{*}$ & $-0.033^{*}$ & $-0.033^{*}$ & $--0.034^{*}$ & $-0.032^{*}$ & $-0.033^{*}$ \\
\hline & $(0.072)$ & $(0.144)$ & $(0.068)$ & $(0.077)$ & $(0.074)$ & $(0.067)$ & $(0.085)$ & $(0.072)$ \\
\hline $\begin{array}{l}\text { Bank } \\
\text { characteristics }\end{array}$ & Yes & Yes & Yes & Yes & Yes & Yes & Yes & Yes \\
\hline $\begin{array}{l}\text { Macroeconomic } \\
\text { factors }\end{array}$ & Yes & Yes & Yes & Yes & Yes & Yes & Yes & Yes \\
\hline Country Dummy & Yes & Yes & Yes & Yes & Yes & Yes & Yes & Yes \\
\hline $\begin{array}{l}\text { Number of } \\
\text { Observations }\end{array}$ & 902 & 902 & 902 & 902 & 902 & 902 & 902 & 902 \\
\hline $\begin{array}{l}\text {-squared } \\
\text { (Overall) }\end{array}$ & 0.5893 & 0.594 & 0.5929 & 0.5934 & 0.5904 & 0.5896 & 0.5900 & 0.5912 \\
\hline
\end{tabular}

Source: Authors' calculations

However, better capital regulation and more restrictions on bank activities are strongly associated with an improved level of efficiency of an IB, whilst the impact of the official supervisory index and private monitoring on the efficiency level is strongly negative (see Table 6). The quality of institutions is strongly correlated with the cost efficiency of both $\mathrm{CBs}$ and IBs. Surprisingly, ownership structure has no role to play in explaining the efficiency of a CB or IB (see Model 1 in each table).

Next, we add an interaction term between regulatory variables and each ownership variable. We find that individually, both government ownership and foreign ownership have strong influence on the cost efficiency of a CB. When they are interacted with regulatory measures, the positive effect of regulations is significant only for $\mathrm{CBs}$ with higher level of government ownership. In contrast, the efficiency performance of IBs does not depend on the type of ownership structure. The interaction effect of regulatory measures and bank ownership structure is found insignificant in all models. There is 
only limited evidence that the effect of capital regulation and private monitoring is more pronounced for banks with higher level of ownership concentration. These findings are in line with our last hypothesis $(\mathrm{H} 4 \mathrm{a})$ : "The effect of bank regulation and ownership on bank efficiency should be different between conventional banks and Islamic banks." As expected, bank-level characteristics are important determinants of bank efficiency. IBs that are listed on a national or international stock exchange are more efficient than private banks.

In Tables 7 and 8 we report our results for bank profitability. We find evidence for a significant influence of regulatory measures (more specifically, the index of official supervisory power and activity restrictions) on the profitability of a CB (see Model 1 in Table 7). As expected, foreign ownership has a negative impact on the profitability of a $\mathrm{CB}$. The results in Table 8 show that only capital regulation is strongly associated with an IB's profitability. We observe a significant difference between the two samples when the interaction term is introduced in the model. We find that the influence of regulatory measures on the profitability of a CB does not depend on the ownership structure of the bank (except for the interaction effect between private monitoring and ownership concentration). In contrast, the interaction effect of regulatory measures and different types of ownership is strongly significant in the sample of Islamic banks. This contradicts our last hypothesis $(\mathrm{H} 4 \mathrm{~b})$ : "The effect of bank regulation and ownership on bank profitability should not depend on whether a bank is conventional or Islamic bank." The negative association of the quality of institutions with bank profitability is significant only in the sample of CBs. However, in both samples, banks that are taking on more risk, are more profitable. In contrast to CBs, the profitability of an IB does not depend on whether the bank is a public or private entity.

Table 7: Panel regressions of bank profitability (Conventional Banks, 2005-2015)

\begin{tabular}{|l|c|c|c|c|c|c|c|c}
\hline $\begin{array}{l}\text { Explanatory } \\
\text { Variables }\end{array}$ & Model 1 & Model 2 & Model 3 & Model 4 & Model 5 & Model 6 & Model 7 & Model 8 \\
\hline Constant & $0.153^{* *}$ & $0.152^{* *}$ & $0.154^{* *}$ & $0.153^{* *}$ & $0.153^{* *}$ & $0.149^{* *}$ & $0.153^{* *}$ & $0.148^{* *}$ \\
\hline & $(0.018)$ & $(0.019)$ & $(0.018)$ & $(0.019)$ & $(0.019)$ & $(0.022)$ & $(0.019)$ & $(0.023)$ \\
\hline Official & $-0.010^{* * *}$ & $-0.008^{* *}$ & $-0.010^{* * *}$ & $-0.011^{* * *}$ & $-0.011^{* * *}$ & $-0.010^{* * *}$ & $-0.011^{* * *}$ & $-0.010^{* * *}$ \\
\hline & $(0.004)$ & $(0.044)$ & $(0.005)$ & $(0.005)$ & $(0.002)$ & $(0.004)$ & $(0.003)$ & $(0.003)$ \\
\hline Capital & -0.006 & -0.000 & -0.005 & -0.004 & -0.006 & -0.008 & -0.006 & -0.006 \\
\hline & $(0.368)$ & $(0.957)$ & $(0.432)$ & $(0.529)$ & $(0.400)$ & $(0.264)$ & $(0.389)$ & $(0.367)$ \\
\hline Restrict & $0.009^{* *}$ & $0.007^{*}$ & $0.009^{* *}$ & $0.008^{* *}$ & $0.009^{* *}$ & $0.009^{* *}$ & $0.007^{* *}$ & $0.009^{* * *}$ \\
\hline & $(0.011)$ & $(0.064)$ & $(0.012)$ & $(0.030 \mid)$ & $(0.011)$ & $(0.010)$ & $(0.032)$ & $(0.008)$ \\
\hline Private Monitoring & 0.008 & 0.000 & 0.007 & 0.008 & 0.008 & 0.008 & 0.008 & 0.006 \\
\hline & $(0.127)$ & $(0.963)$ & $(0.199)$ & $(0.164)$ & $(0.137)$ & $(0.135)$ & $(0.135)$ & $(0.295)$ \\
\hline Ownership & 0.021 & -0.013 & 0.020 & 0.022 & 0.001 & -0.006 & -0.011 & -0.026 \\
\hline & $(0.329)$ & $(0.653)$ & $(0.343)$ & $(0.289)$ & $(0.970)$ & $(0.836)$ & $(0.732)$ & $(0.421)$ \\
\hline Government & -0.035 & -0.030 & -0.079 & -0.034 & -0.064 & -0.058 & -0.058 & -0.054 \\
\hline & $(0.401)$ & $(0.482)$ & $(0.153)$ & $(0.411)$ & $(0.258)$ & $(0.291)$ & $(0.290)$ & $(0.324)$ \\
\hline Foreign & $-0.079^{* * *}$ & $-0.076^{* * *}$ & $-0.078^{* * *}$ & $-0.086^{* *}$ & $-0.078^{* *}$ & $-0.064^{*}$ & $-0.072^{*}$ & $-0.052^{*}$ \\
\hline & $(0.004)$ & $(0.005)$ & $(0.004)$ & $(0.021)$ & $(0.050)$ & $(0.102)$ & $(0.070)$ & $(0.099)$ \\
\hline
\end{tabular}




\begin{tabular}{|c|c|c|c|c|c|c|c|c|}
\hline Official $\times O C$ & & -0.008 & & & 0.003 & & & \\
\hline & & $(0.330)$ & & & $(0.440)$ & & & \\
\hline Capital x OC & & -0.023 & & & & 0.007 & & \\
\hline & & $(0.154)$ & & & & $(0.254)$ & & \\
\hline Restrict $x O C$ & & 0.008 & & & & & 0.005 & \\
\hline & & $(0.370)$ & & & & & $(0.179)$ & \\
\hline Priv Monitor $\times O C$ & & $0.031^{* *}$ & & & & & & $0.011^{*}$ \\
\hline & & $(0.041)$ & & & & & & $(0.061)$ \\
\hline Official x GO & & & 0.002 & & 0.006 & & & \\
\hline & & & $(0.882)$ & & $(0.419)$ & & & \\
\hline Capital x GO & & & -0.029 & & & 0.012 & & \\
\hline & & & $(0.582)$ & & & $(0.386)$ & & \\
\hline Restrict $x$ GO & & & -0.014 & & & & 0.007 & \\
\hline & & & $(0.698)$ & & & & $(0.414)$ & \\
\hline Priv Monitor $x$ GO & & & 0.052 & & & & & 0.009 \\
\hline & & & $(0.311)$ & & & & & $(0.423)$ \\
\hline Official x FO & & & & 0.003 & 0.000 & & & \\
\hline & & & & $(0.793)$ & $(0.970)$ & & & \\
\hline Capital x FO & & & & -0.022 & & -0.003 & & \\
\hline & & & & $(0.367)$ & & (0.645) & & \\
\hline Restrict $x F O$ & & & & 0.013 & & & -0.000 & \\
\hline & & & & $(0.381)$ & & & $(0.913)$ & \\
\hline Priv Monitor $x$ FO & & & & -0.000 & & & & -0.005 \\
\hline & & & & $(0.977)$ & & & & $(0.443)$ \\
\hline Institution & $-0.107^{\star \star}$ & $-0.106^{* \star}$ & $-0.107^{\star *}$ & $-0.115^{* *}$ & $-0.109^{* *}$ & $-0.106^{\star \star}$ & $-0.110^{\star \star}$ & $-0.106^{* *}$ \\
\hline & $(0.027)$ & $(0.028)$ & $(0.028)$ & $(0.018)$ & $(0.024)$ & $(0.028)$ & $(0.022)$ & $(0.027)$ \\
\hline LISTED_D & $-0.032^{* *}$ & $-0.033^{* *}$ & $-0.033^{* *}$ & $-0.032^{* *}$ & $-0.033^{* *}$ & $-0.033^{* *}$ & $-0.033^{* *}$ & $-0.033^{* *}$ \\
\hline & $(0.038)$ & $(0.033)$ & $(0.032)$ & $(0.037)$ & $(0.033)$ & $(0.033)$ & $(0.032)$ & $(0.031)$ \\
\hline CRISIS D & -0.019 & -0.019 & -0.019 & -0.020 & -0.019 & -0.019 & -0.019 & -0.019 \\
\hline & $(0.218)$ & $(0.222)$ & $(0.231)$ & $(0.209)$ & $(0.218)$ & $(0.224)$ & $(0.224)$ & $(0.230)$ \\
\hline $\begin{array}{l}\text { Bank } \\
\text { characteristics }\end{array}$ & Yes & Yes & Yes & Yes & Yes & Yes & Yes & Yes \\
\hline Macroeconomic & Yes & Yes & Yes & Yes & Yes & Yes & Yes & Yes \\
\hline Country Dummy & Yes & Yes & Yes & Yes & Yes & Yes & Yes & Yes \\
\hline $\begin{array}{l}\text { Number of } \\
\text { Observations }\end{array}$ & 2507 & 2507 & 2507 & 2507 & 2507 & 2507 & 2507 & 2507 \\
\hline $\begin{array}{l}R \text {-squared } \\
\text { (Overall) }\end{array}$ & 0.0952 & 0.0981 & 0.0961 & 0.0958 & 0.0960 & 0.0962 & 0.0965 & 0.0973 \\
\hline
\end{tabular}

Source: Authors' calculations

Table 8: Panel regressions of bank profitability (Islamic banks, 2005-2015)

\begin{tabular}{|l|c|c|c|c|c|c|c|c|}
\hline $\begin{array}{l}\text { Explanatory } \\
\text { Variables }\end{array}$ & Model 1 & Model 2 & Model 3 & Model 4 & Model 5 & Model 6 & Model 7 & Model 8 \\
\hline Constant & $-0.188^{* *}$ & $-0.151^{*}$ & $-0.158^{*}$ & -0.014 & 0.069 & 0.058 & -0.128 & 0.081 \\
\hline & $(0.038)$ & $(0.103)$ & $(0.075)$ & $(0.797)$ & $(0.537)$ & $(0.601)$ & $(0.177)$ & $(0.463)$ \\
\hline Official & -0.001 & -0.006 & 0.001 & 0.002 & 0.000 & 0.001 & 0.000 & 0.000 \\
\hline & $(0.976)$ & $(0.336)$ & $(0.725)$ & $(0.662)$ & $(0.998)$ & $(0.885)$ & $(0.956)$ & $(0.949)$ \\
\hline Capital & $-0.024^{* *}$ & $-0.029^{* *}$ & $-0.021^{* *}$ & $-0.022^{* *}$ & $-0.027^{* *}$ & $-0.029^{* *}$ & $-0.025^{* *}$ & $-0.024^{* *}$ \\
\hline & $(0.029)$ & $(0.026)$ & $(0.050)$ & $(0.050)$ & $(0.018)$ & $(0.010)$ & $(0.024)$ & $(0.033)$ \\
\hline Restrict & 0.006 & $0.022^{* *}$ & 0.000 & 0.000 & 0.004 & 0.005 & 0.003 & 0.006 \\
\hline & $(0.397)$ & $(0.016)$ & $(0.972)$ & $(0.966)$ & $(0.504)$ & $(0.456)$ & $(0.647)$ & $(0.344)$ \\
\hline Private Monitoring & 0.004 & -0.005 & 0.007 & 0.006 & 0.006 & 0.006 & 0.006 & 0.001 \\
\hline
\end{tabular}




\begin{tabular}{|c|c|c|c|c|c|c|c|c|}
\hline & $(0.535)$ & $(0.549)$ & $(0.302)$ & $(0.398)$ & $(0.434)$ & $(0.433)$ & $(0.346)$ & (0.933) \\
\hline \multirow[t]{2}{*}{ Ownership } & -0.008 & -0.074 & -0.031 & -0.040 & $-0.087^{*}$ & $-0.095^{\star *}$ & -0.037 & $-0.125^{*}$ \\
\hline & $(0.778)$ & $(0.116)$ & $(0.275)$ & $(0.178)$ & $(0.076)$ & $(0.049)$ & $(0.432)$ & $(0.012)$ \\
\hline \multirow{2}{*}{ Government } & $-0.100^{*}$ & -0.051 & -0.017 & -0.005 & 0.023 & 0.038 & -0.030 & 0.058 \\
\hline & $(0.070)$ & $(0.398)$ & $(0.759)$ & $(0.919)$ & $(0.718)$ & $(0.556)$ & $(0.646)$ & $(0.377)$ \\
\hline \multirow[t]{2}{*}{ Foreign } & $0.209^{* \star *}$ & $0.214^{\star \star *}$ & $0.188^{\star * *}$ & $0.196^{\star * *}$ & $0.136^{*}$ & 0.110 & 0.092 & $0.192^{* \star}$ \\
\hline & $(0.000)$ & $(0.000)$ & $(0.000)$ & $(0.000)$ & $(0.092)$ & $(0.169)$ & $(0.249)$ & $(0.021)$ \\
\hline \multirow[t]{2}{*}{ Official $x$ OC } & & 0.017 & & & $0.009^{*}$ & & & \\
\hline & & $(0.321)$ & & & $(0.086)$ & & & \\
\hline \multirow[t]{2}{*}{ Capital $\times \mathrm{OC}$} & & $0.014^{* \star}$ & & & & $0.016^{*}$ & & \\
\hline & & $(0.020)$ & & & & $(0.056)$ & & \\
\hline \multirow[t]{2}{*}{ Restrict $x O C$} & & $-0.050^{* * *}$ & & & & & $0.004^{*}$ & \\
\hline & & $(0.005)$ & & & & & $(0.489)$ & \\
\hline \multirow[t]{2}{*}{ Priv Monitor $x O C$} & & $0.035^{\star}$ & & & & & & $0.020^{* *}$ \\
\hline & & $(0.052)$ & & & & & & $(0.010)$ \\
\hline \multirow[t]{2}{*}{ Official x GO } & & & -0.027 & & $-0.062^{* * *}$ & & & \\
\hline & & & $(0.640)$ & & $(0.000)$ & & & \\
\hline \multirow[t]{2}{*}{ Capital x GO } & & & $0.331^{* *}$ & & & $-0.130^{\star * *}$ & & \\
\hline & & & $(0.049)$ & & & $(0.000)$ & & \\
\hline \multirow[t]{2}{*}{ Restrict $x$ GO } & & & $0.767^{* * *}$ & & & & $-0.054^{* * *}$ & \\
\hline & & & $(0.000)$ & & & & $(0.004)$ & \\
\hline \multirow[t]{2}{*}{ Priv Monitor x GO } & & & $-1.207^{* * \star}$ & & & & & $-0.092^{* *}$ \\
\hline & & & $(0.000)$ & & & & & $(0.000)$ \\
\hline \multirow[t]{2}{*}{ Official $x$ FO } & & & & -0.034 & $0.012^{*}$ & & & \\
\hline & & & & $(0.554)$ & $(0.107)$ & & & \\
\hline \multirow[t]{2}{*}{ Capital x FO } & & & & $0.328^{*}$ & & $0.022^{*}$ & & \\
\hline & & & & $(0.052)$ & & $(0.091)$ & & \\
\hline \multirow[t]{2}{*}{ Restrict $x F O$} & & & & $0.769^{\star * *}$ & & & $0.018^{*}$ & \\
\hline & & & & $(0.000)$ & & & $(0.072)$ & \\
\hline \multirow[t]{2}{*}{ Priv Monitor x GO } & & & & $-1.198^{* \star *}$ & & & & $0.005^{\star *}$ \\
\hline & & & & $(0.000)$ & & & & $(0.049)$ \\
\hline \multirow[t]{2}{*}{ Institution } & -0.028 & -0.010 & -0.002 & -0.003 & -0.002 & -0.004 & -0.020 & -0.006 \\
\hline & $(0.676)$ & $(0.874)$ & $(0.967)$ & $(0.962)$ & $(0.966)$ & $(0.948)$ & $(0.762)$ & $(0.926)$ \\
\hline \multirow[t]{2}{*}{ LISTED_D } & -0.015 & -0.019 & -0.013 & -0.013 & -0.007 & -0.007 & -0.009 & -0.008 \\
\hline & $(0.418)$ & $(0.306)$ & $(0.465)$ & $(0.459)$ & $(0.682)$ & $(0.701)$ & $0.615)$ & $(0.656)$ \\
\hline \multirow[t]{2}{*}{ CRISIS_D } & -0.021 & -0.024 & -0.030 & -0.027 & -0.030 & -0.033 & -0.026 & -0.030 \\
\hline & $(0.332)$ & $(0.264)$ & $(0.151)$ & $(0.213)$ & $(0.155)$ & $(0.111)$ & $(0.220)$ & $(0.157)$ \\
\hline $\begin{array}{l}\text { Bank } \\
\text { characteristics }\end{array}$ & Yes & Yes & Yes & Yes & Yes & Yes & Yes & Yes \\
\hline Macroeconomic & Yes & Yes & Yes & Yes & Yes & Yes & Yes & Yes \\
\hline Country Dummy & Yes & Yes & Yes & Yes & Yes & Yes & Yes & Yes \\
\hline $\begin{array}{l}\text { Number of } \\
\text { Observations }\end{array}$ & 902 & 902 & 902 & 902 & 902 & 902 & 902 & 902 \\
\hline $\begin{array}{l}R \text {-squared } \\
\text { (Overall) }\end{array}$ & 0.1465 & 0.1587 & 0.1855 & 0.1822 & 0.1608 & 0.1686 & 0.1594 & 0.1652 \\
\hline
\end{tabular}

Source: Authors' calculations

\subsection{Bank efficiency and bank profitability before and after the crisis}

In the previous analysis, we find that the crisis dummy is strongly significant, and thus we expect the determinants of bank performance to be different before and after the 
global financial crisis. We observed that IBs are more profitable than CBs but not after the crisis. Furthermore, IBs are more cost efficient during the crisis but not in the postcrisis period.

We further investigate this issue by examining the main determinants of bank efficiency and profitability for each group of banks, before and after the crisis. Table 9 reports the results for bank efficiency. In line with our expectations, we find that in the pre-crisis period, regulatory measures have no influence on the cost efficiency of a CB. These effects are also insignificant in the post-crisis period. However, we find opposing results for IBs - all regulatory measures are strongly correlated with the level of efficiency of an IB. Though these effects are weak in the pre-crisis period, after the crisis, the influence of bank regulations on bank efficiency is strongly significant. This provides further evidence of the positive effects from the implementation of the Basel regulations in the MENA region and supports the hypothesis that bank supervisors are able to promote efficient banks in the MENA region (Haque and Brown, 2017).

The effect of ownership structure on the level of bank efficiency is found to be relatively weak whether a bank is a CB or an IB. We only find limited evidence that CBs with higher percentage of ownership concentration or larger share of government ownership are less efficient in the pre-crisis period (see Model 2). In an unreported test, we add an interaction term between regulatory variables and each ownership variable. The results show that before the crisis, the impact of bank regulations on the cost efficiency of a CB is significant only for banks with higher level of foreign ownership. The interaction effect of regulation and bank ownership structure is, however, insignificant in the sample of IBs. In the post-crisis period, the influence of regulations on bank efficiency is more pronounced in the group of IBs, especially for those banks that have higher level of ownership concentration. Specific bank-level characteristics are also important determinants of cost efficiency, both in the pre-crisis and post-crisis periods.

The results reported in Table 10 for bank profitability reveal some interesting differences between the two groups of banks. For example, the evidence shows that regulatory measures do not have an impact on a CB profitability (except private monitoring); however, this effect is strongly significant in the post-crisis period. In line with our third hypothesis, we find that capital regulation and activity restrictions are important determinants of profitability of an IB, both in the pre-crisis and post-crisis periods. Regarding the bank ownership structure, the evidence shows that foreign ownership does have a significant influence on bank profitability, before and after the crisis; this effect is negative for CBs but positive for IBs. To test the effect of regulation and ownership on bank profitability, we run additional regressions with an interaction term between regulatory measures and each ownership variable. The results from an unreported test show that, in the sample of conventional banks, the interaction effect is relatively weak, both before and after the crisis. However, we observe a significant 
impact of regulation and ownership on the profitability of an IB, but not in the pre-crisis period.

\section{Robustness checks and alternative specifications}

For robustness purposes, in addition to the fixed and random effects models (reported in the previous tables), the analysis employs identical specifications using the GMM estimator, developed by Arellano and Bover (1995). This estimator controls for the presence of unobserved firm-specific effects and for the endogeneity of explanatory variables. The instruments used depend on the assumption made as to whether the variables are endogenous or predetermined, or exogenous. Instrument validity is tested using the Sargan test of overidentifying restrictions. According to Stock and Watson (2011), OLS methods produce inconsistent and biased estimates when the variables are jointly determined. The weak strength of available Instrumental Variables (IV) also make the GMM estimator a more appropriate and robust technique than seemingly unrelated regressions, panel-corrected standard error estimates and instrumental variables, or the two-stage least square.

The results of the GMM tests for bank efficiency are reported in Appendix B (not presented here for brevity of reporting). As in Table 3, we run the regression model without an interaction term (Model 1) and with an interaction term (Models 2 to 4). Our findings do not change significantly. We observe that the official supervisory index and capital regulation both individually and interactively have a strong impact on cost efficiency. In models 5 to 8 , we introduce an interaction term between each regulatory variable and the ownership variables one at a time. We find that the influence of regulatory measures on a bank's efficiency does not depend on the type of bank ownership. In line with our second hypothesis, we find that foreign ownership has a positive impact on bank efficiency; however, this effect is weakly correlated with bank regulations. Next, we run the regression model for bank profitability. Similar to Table 4, we find that none of the ownership variables is strongly correlated with bank profitability. Furthermore, the effect of regulation on a bank's profitability does not depend on the bank ownership structure. In line with our previous analysis, important bank-level characteristics and country macroeconomic conditions are significant determinants of bank profitability. However, the profitability does not seem to be determined by whether a bank is a CB or an IB. As expected, private banks are more profitable that listed banks. 
Table 9: Panel regressions of bank efficiency (pre- crisis and post-crisis period)

\begin{tabular}{|l|c|c|c|c|c|c|}
\hline & \multicolumn{3}{|c}{ Conventional Banks } & \multicolumn{3}{c|}{ Islamic Banks } \\
\hline $\begin{array}{l}\text { Explanatory } \\
\text { Variables }\end{array}$ & All & Pre-crisis & Post-crisis & All & Pre-crisis & Post-crisis \\
\hline & Model 1 & Model 2 & Model 3 & Model 4 & Model 5 & Model 6 \\
\hline Constant & $0.228^{* * *}$ & 0.023 & $0.234^{* * *}$ & $0.213^{\star * *}$ & 0.149 & $0.195^{*}$ \\
\hline Official & $(0.000)$ & $(0.923)$ & $(0.000)$ & $(0.006)$ & $(0.507)$ & $(0.063)$ \\
\hline & 0.001 & 0.001 & 0.004 & $0.011^{* *}$ & 0.010 & $0.011^{* *}$ \\
\hline Capital & $(0.772)$ & $(0.904)$ & $(0.129)$ & $(0.015)$ & $(0.531)$ & $(0.049)$ \\
\hline & -0.003 & 0.011 & -0.007 & $-0.032^{* * *}$ & -0.021 & $-0.031^{* *}$ \\
\hline Restrict & $(0.581)$ & $(0.564)$ & $(0.184)$ & $(0.001)$ & $(0.690)$ & $(0.050)$ \\
\hline & -0.002 & 0.002 & -0.004 & $-0.013^{* *}$ & -0.002 & $-0.010^{*}$ \\
\hline Private Monitoring & $(0.917)$ & $(0.872)$ & $(0.162)$ & $(0.029)$ & $(0.905)$ & $(0.077)$ \\
\hline & -0.003 & -0.014 & 0.003 & $0.020^{* * *}$ & 0.011 & $0.019^{*}$ \\
\hline $\begin{array}{l}\text { Ownership } \\
\text { concentration }\end{array}$ & $(0.411)$ & $(0.503)$ & $(0.317)$ & $(0.001)$ & $(0.641)$ & $(0.061)$ \\
\hline & 0.011 & $0.061^{* *}$ & -0.015 & -0.017 & -0.023 & -0.017 \\
\hline $\begin{array}{l}\text { Government } \\
\text { ownership }\end{array}$ & $(0.450)$ & $(0.049)$ & $(0.269)$ & $(0.498)$ & $(0.505)$ & $(0.622)$ \\
\hline & 0.040 & $0.206^{* * *}$ & -0.034 & -0.002 & 0.038 & -0.088 \\
\hline Foreign ownership & $(0.040)$ & $(0.003)$ & $(0.189)$ & $(0.995)$ & $0.527)$ & $(0.216)$ \\
\hline & -0.016 & -0.048 & -0.001 & -0.025 & -0.065 & -0.005 \\
\hline Institution & $(0.390)$ & $(0.273)$ & $(0.940)$ & $(0.503)$ & $(0.249)$ & $(0.910)$ \\
\hline & $0.068^{* *}$ & 0.105 & $0.073^{* *}$ & $0.098^{*}$ & 0.210 & 0.091 \\
\hline LISTED_D & $(0.043)$ & $(0.420)$ & $(0.030)$ & $(0.091)$ & $(0.252)$ & $(0.318)$ \\
\hline & -0.016 & -0.010 & -0.013 & $-0.046^{* * *}$ & -0.011 & $-0.068^{* * *}$ \\
\hline CRISIS_D & $(0.123)$ & $(0.644)$ & $(0.196)$ & $(0.004)$ & $(0.597)$ & $(0.002)$ \\
\hline & $-0.014^{*}$ & -- & -- & $-0.033^{*}$ & -- & -- \\
\hline Bank characteristics & $(0.093)$ & -- & -- & $(0.072)$ & -- & -- \\
\hline Macroeconomic & Yes & Yes & Yes & Yes & Yes & Yes \\
\hline Country Dummy & Yes & Yes & Yes & Yes & Yes & Yes \\
\hline $\begin{array}{l}\text { Number of } \\
\text { Observations }\end{array}$ & 2507 & 911 & 1596 & 902 & 328 & 574 \\
\hline R-squared (Overall) & 0.5104 & 0.4396 & 0.6362 & 0.5893 & 0.6688 & 0.5338 \\
\hline
\end{tabular}

Source: Authors' calculations

Table 10: Panel regressions of bank profitability (pre- crisis and post-crisis period)

\begin{tabular}{|l|c|c|c|c|c|c|}
\hline & \multicolumn{3}{|c|}{ Conventional Banks } & \multicolumn{3}{c|}{ Islamic Banks } \\
\hline $\begin{array}{l}\text { Explanatory } \\
\text { Variables }\end{array}$ & All & Pre-crisis & Post-crisis & All & Pre-crisis & Post-crisis \\
\hline & Model 1 & Model 2 & Model 3 & Model 4 & Model 5 & Model 6 \\
\hline Constant & $0.153^{* *}$ & 0.262 & 0.013 & $-0.188^{* *}$ & -0.065 & -0.086 \\
\hline & $(0.018)$ & $(0.289)$ & $(0.888)$ & $(0.038)$ & $(0.820)$ & $(0.609)$ \\
\hline Official & $-0.010^{* * *}$ & -0.016 & -0.000 & -0.000 & 0.003 & $-0.019^{* *}$ \\
\hline & $(0.004)$ & $(0.155)$ & $(0.992)$ & $(0.976)$ & $(0.889)$ & $(0.037)$ \\
\hline Capital & -0.006 & -0.001 & $0.028^{* *}$ & $-0.024^{* *}$ & $-0.125^{*}$ & $-0.030^{*}$ \\
\hline & $(0.368)$ & $(0.964)$ & $(0.010)$ & $(0.029)$ & $(0.069)$ & $(0.100)$ \\
\hline Restrict & $0.009^{* *}$ & -0.010 & -0.002 & 0.006 & $0.064^{* *}$ & $0.060^{* * *}$ \\
\hline Private Monitoring & $(0.011)$ & $(0.459)$ & $(0.653)$ & $(0.397)$ & $(0.015)$ & $(0.001)$ \\
\hline
\end{tabular}




\begin{tabular}{|l|c|c|c|c|c|c|}
\hline & $(0.127)$ & $(0.083)$ & $(0.043)$ & $(0.535)$ & $(0.750)$ & $(0.031)$ \\
\hline $\begin{array}{l}\text { Ownership } \\
\text { concentration }\end{array}$ & 0.021 & 0.001 & 0.021 & -0.008 & -0.000 & 0.007 \\
\hline $\begin{array}{l}\text { Government } \\
\text { ownership }\end{array}$ & $(0.329)$ & $(0.974)$ & $(0.437)$ & $(0.778)$ & $(0.992)$ & $(0.856)$ \\
\hline Foreign ownership & -0.035 & -0.047 & -0.023 & $-0.100^{* *}$ & $-0.192^{* *}$ & -0.001 \\
\hline & $-0.401)$ & $(0.751)$ & $(0.652)$ & $(0.070)$ & $(0.013)$ & $(0.990)$ \\
\hline Institution & $(0.004)$ & $(0.051)$ & $(0.001)$ & $(0.000)$ & $(0.101)$ & $(0.000)$ \\
\hline & $-0.107^{* *}$ & 0.085 & $-0.140^{* *}$ & -0.028 & $0.422^{*}$ & 0.034 \\
\hline LISTED_D & $(0.027)$ & $(0.526)$ & $(0.034)$ & $(0.676)$ & $(0.073)$ & $(0.738)$ \\
\hline & $-0.032^{* *}$ & $-0.034^{* *}$ & $-0.030^{*}$ & -0.015 & 0.007 & -0.021 \\
\hline CRISIS_D & $(0.038)$ & $(0.155)$ & $(0.132)$ & $(0.418)$ & $(0.799)$ & $(0.381)$ \\
\hline & -0.019 & -- & -- & -0.021 & -- & -- \\
\hline Bank characteristics & $(0.218)$ & -- & -- & $(0.332)$ & -- & -- \\
\hline Macroeconomic & Yes & Yes & Yes & Yes & Yes & Yes \\
\hline Country Dummy & Yes & Yes & Yes & Yes & Yes & Yes \\
\hline $\begin{array}{l}\text { Number of } \\
\text { Observations }\end{array}$ & 2507 & 911 & 1596 & 902 & Yes & Yes \\
\hline R-squared (Overall) & 0.0952 & 0.1007 & 0.1486 & 0.1465 & 0.2194 & 0.1992 \\
\hline
\end{tabular}

Source: Authors' calculations

In addition to the regressions discussed in the previous section, we investigate the robustness of our results using alternative specifications and different control variables. Rather than estimating the bank efficiency through CIR, we used an alternative measure - NIM. Similarly, we measure bank profitability using EARGL. The results do not change significantly. Next, we estimate the regressions in Table 3 and 4 using different explanatory variables. For example, instead of institution variable (the index of institution is the average of six indicators), we use four different indices that measure the quality of the institutional environment (see Table 2). The estimation results are not reported here but are available on request. Finally, in line with Ghosh (2016), we test the hypothesis the Arab Spring has an (inverse) impact on bank risk and performance in the MENA region. We introduce a dummy variable (AS_D) that takes the value of 1 for the year of 2010, and 0 otherwise. We also interact this variable with each country dummy in the model. The evidence shows that the country dummy for Arab Spring is strongly significant in all models for bank efficiency. We also find that the country dummy for Libya exhibits a statistically significant and negative association with a bank's efficiency. Similarly, country dummies for Tunisia and Egypt are negatively correlated with bank profitability, indicating some support for the argument that the Arab Spring had a negative effect on bank performance (and risk) in the non-GCC countries. 


\section{Conclusions}

This paper investigates the impact of regulation and ownership on bank performance using a sample of 309 banks in 19 countries from the MENA region. We also address the question of whether the performance of IBs before, during and after the global financial crisis of 2007-2008 is different as compared to CBs.

Using a larger sample of banks and different time span, we find evidence that only capital regulation has a significantly positive influence on bank efficiency, whereas ownership structure seems to play no role in explaining bank efficiency. The relationship between bank regulations and profitability is found to be strongly significant even when we control for specific bank-level and country-level effects. Haque and Brown (2017) find that government ownership of banks has a positive influence on cost efficiency, but not on profit efficiency, whereas foreign banks appear not to have any advantage in the MENA region. In contrast, our results show that a higher level of government ownership is negatively associated with a bank's efficiency, whereas the effect of foreign ownership is positive. Thus, we are unable to support the arguments that government ownership in the financial sector is beneficial in countries with underdeveloped institutions (Otchere, 2005).

Given that bank regulation (and more particularly Basel II regulations) does not differentiate on bank ownership type, it is important to estimate the effect of regulation on bank efficiency and profitability for different types of ownership. The interaction effects between bank regulation and bank ownership resulted in some interesting findings particularly for government owned and foreign banks. For example, even though the individual effect of regulatory measures on cost efficiency is relatively weak (except for capital regulation), when these measures are interacted with the government ownership variable, the impact of regulations is strongly positive. This is in line with the common view that there might be some regulatory benefits provided to government owned banks in the MENA region. Banks with a larger share of foreign ownership seems to be more efficient; however, this positive effect is not associated with the level of bank regulations. Furthermore, we find that capital regulation and official supervisory power are strongly associated with a bank's profitability, but there is no evidence that these effects depend on the type of ownership of the bank.

The question of whether the impact of regulation and ownership is different between conventional and Islamic banking has not been investigated so far. We find no evidence of a significant influence of regulatory measures on cost efficiency of a CB. In comparison, the influence of regulations on bank efficiency is much more pronounced in the sample of IBs; however, this effect is not correlated with the ownership structure of the bank. Our analysis also shows a significant difference in the effect of regulation and ownership on the profitability of a CB and an IB. The impact of regulatory measures on 
bank profitability does not depend on the ownership structure of a CB. In contrast, the interaction effect of bank regulations and different types of bank ownership is strongly significant in the sample of IBs. These results are very important for policy makers as regulators should not treat the two types of banks identically when setting up and implementing bank regulations.

Finally, we estimate the impact of regulation and ownership on bank performance for an extended period before and after the crisis, and find that in the pre-crisis period, regulatory measures have no influence on the cost efficiency of a CB. These effects are also insignificant in the post-crisis period. However, regulatory measures are strongly correlated with the cost efficiency of an IB. Though these effects are weak in the precrisis period, after the crisis, the influence of bank regulations on a bank's efficiency is strongly significant. This again suggests further potential benefits with the implementation of the Basel regulation, especially, in the follow up period of the global financial crisis. Regarding bank ownership structure, the evidence shows that IBs with a higher level of foreign ownership are able to achieve higher profitability (but not efficiency), both in the pre-crisis and post-crisis periods, which provides further support to the global advantage hypothesis in the MENA region (Lensink et al., 2008).

\section{Appendix A}

Table A.1 Dependent and explanatory variables

\begin{tabular}{|c|c|c|}
\hline Variable & Explanation & Data Source \\
\hline \multicolumn{3}{|l|}{ Dependent Variables } \\
\hline $\begin{array}{l}\text { Cost-to-income ratio } \\
\text { (CIR) }\end{array}$ & $\begin{array}{l}\text { The share of bank costs to bank income before provisions } \\
\text { times } 100\end{array}$ & Bankscope/Orbis \\
\hline $\begin{array}{l}\text { Net interest margin } \\
\text { (NIM) }\end{array}$ & $\begin{array}{l}\text { Bank interest income minus bank interest expenses as a } \\
\text { percentage of earning assets }\end{array}$ & Bankscope/Orbis \\
\hline $\begin{array}{l}\text { Earnings to total assets } \\
\text { (EARTA) }\end{array}$ & $\begin{array}{l}\text { Bank interest income minus bank interest expenses as a } \\
\text { percentage of total assets }\end{array}$ & $\begin{array}{l}\text { Authors' calculations based } \\
\text { on Bankscope/Orbis }\end{array}$ \\
\hline $\begin{array}{l}\text { Earnings to gross loans } \\
\text { (EARGL) }\end{array}$ & $\begin{array}{l}\text { Bank interest income minus bank interest expenses as a } \\
\text { percentage of gross loans }\end{array}$ & $\begin{array}{l}\text { Authors' calculations based } \\
\text { on Bankscope/Orbis }\end{array}$ \\
\hline \multirow{2}{*}{\multicolumn{3}{|c|}{ Explanatory Variables }} \\
\hline & & \\
\hline Deposits & $\begin{array}{l}\text { Bank characteristic calculated as deposits divided by total } \\
\text { assets }\end{array}$ & $\begin{array}{l}\text { Bankscope and annual } \\
\text { reports (2005-2015) }\end{array}$ \\
\hline Loans & Bank characteristics calculated as loans over total assets & $\begin{array}{l}\text { Bankscope and annual } \\
\text { reports }(2005-2015)\end{array}$ \\
\hline Tier 1 & $\begin{array}{l}\text { Proxy for capital adequacy defined as the ratio of Tier } 1 \\
\text { capital to risk-weighted assets }\end{array}$ & $\begin{array}{l}\text { Bankscope and annual } \\
\text { reports (2005-2015) }\end{array}$ \\
\hline Tangible Equity & $\begin{array}{l}\text { Proxy for capital adequacy defined as equity divided by } \\
\text { total assets }\end{array}$ & $\begin{array}{l}\text { Bankscope and annual } \\
\text { reports }(2005-2015) \text {; Beltratt } \\
\text { and Stulz }(2012, \text { pp.3-8) }\end{array}$ \\
\hline Liquid Asset & The ratio of liquid assets to total assets & $\begin{array}{l}\text { Bankscope and annual } \\
\text { reports (2005-2015) }\end{array}$ \\
\hline
\end{tabular}




\begin{tabular}{|c|c|c|}
\hline Funding Fragility & $\begin{array}{l}\text { The ratio of the sum of deposits from other banks, other } \\
\text { deposits, and short-term borrowing divided by the total } \\
\text { deposits plus money market and short-term funding }\end{array}$ & $\begin{array}{l}\text { Bankscope and annual } \\
\text { reports (2005-2015); Beltratti } \\
\text { and Stulz (2012, pp.5-8) }\end{array}$ \\
\hline Size & Log of bank's total assets & $\begin{array}{l}\text { Bankscope and annual } \\
\text { reports (2005-2015); Laeven } \\
\text { and Levine (2009, pp.261- } \\
267)\end{array}$ \\
\hline Other Earning Assets & $\begin{array}{l}\text { Proxy for the asset side of the balance sheet calculated as } \\
\text { the ratio between the sum of derivatives and other } \\
\text { securities divided by the sum of loans and other earning } \\
\text { assets }\end{array}$ & $\begin{array}{l}\text { Bankscope and annual } \\
\text { reports (2005-2015); Beltratti } \\
\text { and Stulz (2012, pp.3-8) }\end{array}$ \\
\hline Income Diversity & $\begin{array}{l}\text { The ratio is estimated by subtracting } 1 \text { from the ratio of net } \\
\text { interest income minus other operating income divided by } \\
\text { the total operating income }\end{array}$ & $\begin{array}{l}\text { Bankscope and annual } \\
\text { reports (2005-2015); Beltratti } \\
\text { and Stulz (2012, pp.3-8), } \\
\text { Laeven and Levine (2009. } \\
\text { pp.261-267) }\end{array}$ \\
\hline Non-Interest Income & $\begin{array}{l}\text { The share of operating income that is not due to interest } \\
\text { income }\end{array}$ & $\begin{array}{l}\text { Bankscope and annual } \\
\text { reports (2005-2015); Beltratti } \\
\text { and Stulz (2012, pp.3-8), } \\
\text { Demergüc-Kunt and } \\
\text { Huizinga (2010, pp.629-637) }\end{array}$ \\
\hline Z-score & $\begin{array}{l}\text { Z-score is the distance to default calculated as bank's } \\
\text { ROA plus the capital-to-asset ratio divided by the } \sigma(\mathrm{ROA}) \\
\text { over the period 1996-2007 }\end{array}$ & $\begin{array}{l}\text { Bankscope and annual } \\
\text { reports (2005-2015); Beltratti } \\
\text { and Stulz (2012, pp.3-8), } \\
\text { Laeven and Levine (2009, } \\
\text { pp.261-267) }\end{array}$ \\
\hline \multicolumn{3}{|l|}{ Ownership } \\
\hline $\begin{array}{l}\text { Ownership } \\
\text { concentration }\end{array}$ & $\begin{array}{l}\text { The level of ultimate ownership held by the largest } \\
\text { shareholder }\end{array}$ & $\begin{array}{l}\text { Bankscope/Orbis and annual } \\
\text { reports (2005-2015) }\end{array}$ \\
\hline Government ownership & Proportion of equity held by the government & $\begin{array}{l}\text { Bankscope/Orbis and annual } \\
\text { reports (2005-2015) }\end{array}$ \\
\hline Foreign ownership & Proportion of equity held by foreign investors & $\begin{array}{l}\text { Bankscope/Orbis and annual } \\
\text { reports }(2005-2015)\end{array}$ \\
\hline \multicolumn{3}{|l|}{$\begin{array}{l}\text { Regulation and } \\
\text { Institution }\end{array}$} \\
\hline Official & $\begin{array}{l}\text { "The official supervisory index measures the degree to } \\
\text { which the country's commercial bank supervisory agency } \\
\text { has the authority to take specific actions. The official } \\
\text { supervisory index has a maximum value of } 14 \text { and a } \\
\text { minimum value of } 0 \text {, where larger numbers indicate } \\
\text { greater power." }\end{array}$ & $\begin{array}{l}\text { Barth et al. (2001, 2004, } \\
2008) \text {; World Bank's bank } \\
\text { regulation survey (Survey IV, } \\
2011 \text { ) }\end{array}$ \\
\hline Capital & $\begin{array}{l}\text { "The index of bank capital regulations includes information } \\
\text { on (1) the extent of regulatory requirements regarding the } \\
\text { amount of capital banks must hold and (2) the stringency } \\
\text { of regulations on the source of funds that count as } \\
\text { regulatory capital can include assets other than cash or } \\
\text { government securities, borrowed funds, and whether the } \\
\text { regulatory/supervisory authorities verify the sources of } \\
\text { capital. Large values indicate more stringent capital } \\
\text { regulations. The maximum possible value is nine, while }\end{array}$ & $\begin{array}{l}\text { Barth et al. (2001, 2004, } \\
2008) \text {; World Bank's bank } \\
\text { regulation survey (Survey IV, } \\
2011 \text { ) }\end{array}$ \\
\hline
\end{tabular}




\begin{tabular}{|c|c|c|}
\hline & the minimum possible value is zero." & \\
\hline Restrict & $\begin{array}{l}\text { "The index of overall restrictions on bank activities } \\
\text { measures the degree to which banks face regulatory } \\
\text { restrictions on their activities in (a) securities markets, (b) } \\
\text { insurance, (c) real-estate, and (d) owning shares in non- } \\
\text { financial firms. For each of these four sub-categories, the } \\
\text { value ranges from a } 0 \text { to } 4 \text {, where a } 4 \text { indicates the most } \\
\text { restrictive regulations on this sub-category of bank activity. } \\
\text { Thus, the index of overall restrictions can potentially range } \\
\text { from } 0 \text { to 16." }\end{array}$ & $\begin{array}{l}\text { Barth et al. (2001, 2004, } \\
2008) \text {; World Bank's bank } \\
\text { regulation survey (Survey IV, } \\
2011 \text { ) }\end{array}$ \\
\hline Private Monitoring & $\begin{array}{l}\text { "The private monitoring index measures the degree to } \\
\text { which regulations empower, facilitate, and encourage the } \\
\text { private sector to monitor banks. The private monitoring } \\
\text { index has a maximum value of } 9 \text { and a minimum value of } \\
0 \text {, where larger numbers indicate greater regulatory } \\
\text { empowerment of private monitoring of banks." }\end{array}$ & $\begin{array}{l}\text { Barth et al. (2001, 2004, } \\
2008) \text {; World Bank's bank } \\
\text { regulation survey (Survey IV, } \\
2011 \text { ) }\end{array}$ \\
\hline Institution & The index of institution is the average of six indicators & $\begin{array}{l}\text { The World Bank, WGI 2004- } \\
\text { 2015; Kaufmann et al. } \\
\text { (2008) }\end{array}$ \\
\hline State & $\begin{array}{l}\text { State takes value } 1 \text { if the state's stake in a bank exceeds } \\
10 \% \text {. }\end{array}$ & $\begin{array}{l}\text { Bankscope/Orbis and annual } \\
\text { reports }(2005-2015) \text {; Beltratti } \\
\text { and Stulz }(2012, \text { pp.3-8) }\end{array}$ \\
\hline \multicolumn{3}{|l|}{$\begin{array}{l}\text { Macroeconomic } \\
\text { Variables }\end{array}$} \\
\hline Log GDP & $\begin{array}{l}\text { The log of GDP per capita (current \$), proxy for market } \\
\text { size }\end{array}$ & $\begin{array}{l}\text { The World Bank } \\
\text { Development Indicators, } \\
2005-2015\end{array}$ \\
\hline GDP Growth & $\begin{array}{l}\text { Annual percentage growth rate of GDP (constant } 2005 \\
\text { U.S. dollars), proxy for market size }\end{array}$ & $\begin{array}{l}\text { The World Bank } \\
\text { Development Indicators, } \\
2005-2015\end{array}$ \\
\hline Current Account & $\begin{array}{l}\text { Current account is the ratio between the current account } \\
\text { deficit and GDP for } 2007 \text { and } 2008\end{array}$ & $\begin{array}{l}\text { The World Bank } \\
\text { Development Indicators, } \\
2005-2015\end{array}$ \\
\hline Inflation & $\begin{array}{l}\text { Inflation is measured by the consumer price index, in } \\
\text { percent }\end{array}$ & $\begin{array}{l}\text { The World Bank } \\
\text { Development Indicators, } \\
2005-2015\end{array}$ \\
\hline \multicolumn{3}{|l|}{ Quality of institutions } \\
\hline $\begin{array}{l}\text { Political Stability and } \\
\text { Absence of Violence }\end{array}$ & $\begin{array}{l}\text { Average of the following sub-indicators: 1) Government } \\
\text { stability, 2) Internal conflict, 3) External conflict, and 4) } \\
\text { Ethnic tensions }\end{array}$ & $\begin{array}{lll}\text { International } & \text { Country } & \text { Risk } \\
\text { Guide, } 1996 \text { - } 2016 & \end{array}$ \\
\hline Regulatory Quality & $\begin{array}{l}\text { This is an assessment of factors affecting the risk to } \\
\text { investment that are not covered by other political, } \\
\text { economic and financial risk components. The risk rating } \\
\text { assigned is the sum of three subcomponents, each with a } \\
\text { maximum score of four points and a minimum score of } 0 \\
\text { points. A score of } 4 \text { points equates to Very Low Risk and a } \\
\text { score of } 0 \text { points to Very High Risk. }\end{array}$ & $\begin{array}{lll}\text { International Country } & \text { Risk } \\
\text { Guide, } 1996 \text { - } 2016 & \end{array}$ \\
\hline Rule of Law & $\begin{array}{l}\text { Measure of the law and order tradition of a country. It } \\
\text { ranges from } 6 \text {, strong law and order tradition, to } 1 \text {, weak } \\
\text { law and order tradition. }\end{array}$ & $\begin{array}{lll}\text { International } & \text { Country } & \text { Risk } \\
\text { Guide, } 1996 \text { - } 2016 & \end{array}$ \\
\hline
\end{tabular}


Control of Corruption

Source: Orbis and World Bank data bases

\section{References}

Abedifar, P., Tarazi, A., Molyneux, P., 2013. Risk in Islamic banking. Review of Finance 17, 2035-2096.

Agoraki, M. K., Delis, M. D., Pasiouras, F., 2011. Regulation, competition and bank risk-taking in transition countries. Journal of Financial Stability 7, 38-48.

Alqahtani, F., Mayes, D., Brown, K., 2016. Economic turmoil and Islamic banking: Evidence from the Gulf Cooperation Council. Pacific-Basin Finance Journal 39, 44-56.

Al-Tamimi, H. A., Al-Amiri, A., 2003. Analyzing service quality in the UAE Islamic banks. Journal of Financial Services Marketing 8(2), 119-132.

Amba, M. S., Almukharreq, F., 2013. Impact of the financial crisis on profitability of the Islamic banks vs conventional banks: Evidence from GCC, International Journal of Financial Research 4(3), 83-93,

Anginer, D., Demirgüç-Kunt, A., 2014. Bank capital and systemic stability. Policy Research Working Paper No. 6948. The World Bank, Washington, DC.

Arellano, M., \& Bover, O., 1995. Another look at the instrumental variable estimation of error-components models. Journal of Econometrics 68, 29-51.

Awartani, B., Belkhir, M., Boubaker, S., Maghyereh, A., 2016. Corporate debt maturity in the MENA region: Does institutional quality matter? International Review of Financial Analysis 46, 309-325.

Ayadi R., De Groen W.P., 2013. Banking and insurance in the GCC countries: Is there regulatory convergence with the EU? Sharaka Research Paper No. 4, Available at

http://www.ceps.eu/book/banking-and-insurance-gcc-countries-there-regulatory-convergence-eu

Barth, J. R., Caprio, G., Jr., Levine, R., 2001. The regulation and supervision of bank around the world: A new database. In: Litan, R.E., Herring R. (Eds.), Brookings-Wharton Paper on Financial Services, pp. 183-240. Washington DC: Brookings Institution Press.

Barth, J. R., Caprio, G., Jr., Levine, R., 2004. Bank regulation and supervision: What works best? Journal of Financial Intermediation 12, 205-248.

Barth J.R., Caprio Jr. G., Levine R., 2008. Bank regulations are changing: For better or worse? World Bank Policy Research Working Paper, No. 4646, Washington, DC., Available at https://papers.ssrn.com/sol3/papers.cfm?Abstract id=1149579\#\#

Barth, J. R., Lin, C., Ma, Y., Seade, J., Song, F. M., 2013. Do bank regulation, supervision and monitoring enhance or impede bank efficiency? Journal of Banking and Finance 37, 2879-2892.

Beck, T., Demirguc-Kunt, A., Merrouche, O., 2010. Islamic vs. conventional banking. Business model, efficiency and stability. World Bank Working Paper No. 5446. Washington, DC.

Beck T., Demirgüç-Kunt A., Merrouche O., 2013. Islamic vs. conventional banking: Business model, efficiency and stability, Journal of Banking \& Finance 37, 433-447.

Belanès, A., Ftiti, Z., Regaïeg, R., 2015. What can we learn about Islamic banks efficiency under the subprime crisis? Evidence from GCC Region, Pacific-Basin Finance Journal 33, 81-92. 
Beltratti, A., Stulz, R.M., 2012. The credit crisis around the globe: Why did some banks perform better? Journal of Financial Economics 105, 1-17.

Bitar, M., Saad, W., Benlemlih, M., 2016. Bank risk and performance in the MENA region: The importance of capital requirements. Economic Systems 40, 398-421, Available at https://www.researchgate.net/publication/304577657.

Chortareas, G. E., Girardone, C., Ventouri, A., 2012. Bank supervision, regulation, and efficiency: Evidence from the European Union. Journal of Financial Stability 8, 292-302.

Cihak M., Hesse H., 2008. Islamic Banks and Financial Stability: An Empirical Analysis, IMF Working Paper No. 16, Available at: https://www.imf.org/external/pubs/ft/wp/2008/wp0816.pdf.

Daher, H., Masih, M., Ibrahim, M., 2015. The unique risk exposures of Islamic banks' capital buffers: A dynamic panel data analysis. Journal of International Financial Markets Institutions and Money, 36, $36-52$.

Demirgüc-Kunt, A., Huizinga, H., 1999. Determinants of commercial bank interest margins and profitability: Some international evidence. World Bank Economic Review 13, 379-408.

Demirgüc-Kunt, A., Huizinga, H., 2010. Bank activity and funding strategies: the impact on risk and return, Journal of Financial Economics 98, pp.626-650.

Demirgüç-Kunt, A., Detragiache, E., Merrouche, O., 2013. Bank capital: lessons from the financial crisis. Journal of Money Credit Bank 45(6), 1147-1164.

Espinosa, R., Prasad, A., 2010. Nonperforming Loans in the GCC Banking System and their Macroeconomic Effects, IMF Working paper 224, Available at: http://www.imf.org/external/pubs/tt/wp/2010/wp10224.pdf.

Grassa, R., 2012. Islamic banks' income structure and risk: Evidence from GCC countries. Accounting Research Journal 25, 227-241.

Haque, F., Brown, K., 2017. Bank ownership, regulation and efficiency: Perspectives from the Middle East and North Africa (MENA) Region, International Review of Economics and Finance 47, 273 293.

Hasan, M., Dridi, J., 2010. The effect of the global crisis on Islamic and conventional banks: A comparative study. IMF working paper 201. Washington, DC: IMF.

Haw, I.-M., Ho, S., Hu, B., Wu, D., 2010. Concentrated control, institutions, and banking sector: An international study. Journal of Banking and Finance 34, 485-497.

lannotta, G., Nocera, G., Sironi, A., 2007. Ownership structure, risk and performance in the European banking industry. Journal of Banking and Finance 31, 2127-2149.

Kaufmann, D., Kraay, A., \& Mastruzzi, M., 2008. Governance matters VII: Aggregate and individual governance indicators, 1996-2007. Unpublished working paper. World Bank, Washington, DC.

Khan, M. S., Senhadji, A.S., 2000. Financial Development and Economic Growth: An Overview, IMF Working Paper No. WP/00/209.

Kobeissi, N., Sun, X., 2010. Ownership structure and bank performance: Evidence from the Middle East and North Africa region. Comparative Economic Studies 52, 287-323.

Koldertsova, A., 2011. The second corporate governance wave in the Middle East and North Africa. OECD Journal: Financial Market Trends 2, 1-8. 
Kosmidou, K., Pasiouras, F., Tsaklanganos, A., 2007. Domestic and multinational determinants of foreign bank profits: The case of Greek banks operating abroad. Journal of Multinational Financial Management 17, 1-15.

Laeven, L., Levine, R., 2009. Bank governance, regulation and risk taking, Journal of Financial Economics 93, 259-275.

La Porta, L., Lopez-de-Silanes, F., Shleifer, A., Vishny, A., 2002. Investor protection and corporate valuation. Journal of Finance 57, 1147-1170.

Lensink, R., Meesters, Naaborg, I., 2008. Bank efficiency and foreign ownership: Do good institutions matter? Journal of Banking and Finance 32, 834-844.

Levine, R., 1997. Financial development and economic growth: Views and agenda, Journal of Economic Literature 35, 688-726.

Levine, R., Zervos, S., 1998. Stock markets, banks, and growth, American Economic Review 88, 537558.

Micco, A., Panizza, U., Yaez, M., 2007. Bank ownership and performance: Does politics matter? Journal of Banking and Finance 31, 219-241.

Mollah, S., Hassan, M., Farooque, O., Mobarek, A., 2017. The governance, risk-taking, and performance of Islamic banks. Journal of Financial Services Research 51(2), 195-219. Available at http://dx.doi.org/10.1007/s10693-016-0245-2.

Olson, D., Zoubi, T. (2011). Efficiency and bank profitability in MENA countries. Emerging Markets Review 12, 94-110.

Omran, M. M., Bolbol, A., Fatheldin, A., 2008. Corporate governance and firm performance in Arab equity markets: Does ownership concentration matter? International Review of Law and Economics 28, 32-45.

Otchere, I., 2005. Do privatized banks in middle- and low-income countries perform better than rival banks? An intra-industry analysis of bank privatization. Journal of Banking and Finance 29, 20672093.

Pasiouras, F., Tanna, S., Zopounidis, C., 2009. The impact of banking regulation on banks' cost and profit efficiency: Cross-country evidence. International Review of Financial Analysis 18, 294-302.

Rao, A., 2002. Estimation of Efficiency, Scale \& Scope and Productivity Measures of UAE Banks, European Conference of Financial Management Association, Copenhagen.

Rocha R. R., Arvai Z., Farazi S., 2011. Financial access and stability: A road map for the Middle East and North Africa. MENA development report. Washington, DC: World Bank. Available at: http://documents.worldbank.org/curated/en/343771468052798123/Financial-access-and-stability-aroad-map-for-the-Middle-East-and-North-Africa

Sassi, H., 2013. The impact of bank regulation and institutions on efficiency in selected MENA banks. International Journal of Economics and Finance 5, 84-100.

Shafique, A., Faheem, M.A., Abdullah, I., 2012. Impact of global financial crises on the Islamic banking system: analysis of Islamic financial system during financial crunch 2008. Arabian Journal of Business and Management Review 1(9), 124-134. 
Shehzad, C. T., De Haan, J., Scholtens, B., 2010. The impact of ownership concentration on impaired loans and capital adequacy. Journal of Banking and Finance 34, 399-408.

Shleifer, A., Vishny, R. W. (1997). A survey of corporate governance. Journal of Finance 52, 737-783.

Stock, J. H., Watson, M. W., 2011. Introduction to Econometrics, third ed. Addison-Wesley, Boston, MA.

Van Horen, N., 2007. Foreign banks in developing countries: Origin matters. Emerging Markets Review 8 , 81-105.

Zeaiter, H., El-Khalil, R., 2016. Extreme bounds of sovereign defaults: Evidence from the MENA region, International Review of Economics and Finance 41, 391-410.

IMF, 2008. Implementation of Basel core principles for effective banking supervision experience with assessments and implications for future work. Washington, DC: Monetary and Capital Market Department, International Monetary Fund.

The World Bank Worldwide Governance Indicators, 2015. Interactive Data Access [Online]. Available at: http://info.worldbank.org/governance/wgi/index.aspx\#reports (Accessed 15/07/2017).

The World Bank Development Indicators, 2005-2015. World Development Indicators [Online]. Available at: http://data.worldbank.org/indicator/NY.GDP.MKTP.CD (Accessed 15/07/2017). 